NBER WORKING PAPER SERIES

\title{
THE COSTS OF CORPORATE TAX COMPLEXITY
}

\author{
Eric Zwick \\ Working Paper 24382 \\ http://www.nber.org/papers/w24382 \\ NATIONAL BUREAU OF ECONOMIC RESEARCH \\ 1050 Massachusetts Avenue \\ Cambridge, MA 02138 \\ March 2018
}

Some of the results in this paper previously circulated in working papers with the titles, "The Role of Experts in Fiscal Policy Transmission" and "Do Experts Help Firms Optimize?" We thank Steve Bond, Jediphi Cabal, Gary Chamberlain, Raj Chetty, David Cutler, John Friedman, Ed Glaeser, Michelle Hanlon, Nathan Hendren, Rebecca Lester, Andrew Lyon, Ruud de Mooij, Paul Goldsmith-Pinkham, John Graham, Lisa Rupert, Eugene Soltes, Adi Sunderam, Erin Towery, Danny Yagan, and seminar and conference participants for comments and ideas. Jessica Henderson, Prab Upadrashta, and Caleb Wroblewski provided excellent research assistance. We are grateful to our colleagues in the U.S. Treasury Office of Tax Analysis and the IRS Office of Research, Analysis and Statistics - especially Curtis Carlson, John Guyton, Barry Johnson, Jay Mackie, Rosemary Marcuss, and Mark Mazur-for making this work possible. We also thank George Contos, Ronald Hodge, Patrick Langetieg, and Brenda Schafer for help understanding the IRS data systems and the U.S. tax code. The views expressed here are ours and do not necessarily reflect those of the U.S. Treasury Office of Tax Analysis, nor the IRS Office of Research, Analysis and Statistics. Zwick gratefully acknowledges the University of Chicago Booth School of Business, the Neubauer Family Foundation, and the Harvard Business School Doctoral Office for financial support. The views expressed herein are those of the authors and do not necessarily reflect the views of the National Bureau of Economic Research.

NBER working papers are circulated for discussion and comment purposes. They have not been peer-reviewed or been subject to the review by the NBER Board of Directors that accompanies official NBER publications.

(C) 2018 by Eric Zwick. All rights reserved. Short sections of text, not to exceed two paragraphs, may be quoted without explicit permission provided that full credit, including $\bigcirc$ notice, is given to the source. 
The Costs of Corporate Tax Complexity

Eric Zwick

NBER Working Paper No. 24382

March 2018

JEL No. D22,D92,E62,H2,H25,H3

\section{ABSTRACT}

Does tax code complexity alter corporate behavior? This paper investigates this question by focusing on the decision to claim refunds for tax losses. In a sample of $1.2 \mathrm{M}$ observations from the population of corporate tax returns, only $37 \%$ of eligible firms claim their refund. A simple cost-benefit analysis of the tax loss choice cannot explain low take-up, which motivates an investigation of how tax complexity alters this calculation. A research design exploiting tax preparer switches, deaths, and relocations shows that sophisticated preparers increase the claiming behavior of small and mid-market firms. Tax complexity decreases take-up among large firms through interactions of refund claims with other tax code provisions and with the audit process.

Eric Zwick

Booth School of Business

University of Chicago

5807 South Woodlawn Avenue

Chicago, IL 60637

and NBER

ezwick@chicagobooth.edu 
Comprehensive tax reform designed to simplify the corporate tax code last occurred in the United States in 1986. Since then, a proliferation of new provisions, subsidies, credits, and loopholes has sparked calls for simplifying reforms, with policymakers, taxpayers, and even the tax authority expressing concern that tax code complexity distorts behavior and undermines economic efficiency. ${ }^{1}$ In addition, fiscal stimulus often operates through the tax code, but policy design rarely considers whether complexity affects policy transmission. Does tax code complexity alter corporate behavior?

To investigate this question, this paper focuses on the decision by corporate taxpayers to claim refunds for net operating losses. The treatment of losses is a permanent feature of the tax code that affects most firms, enabling a large, representative analysis in a setting where policy awareness is stable over time. Tax refunds for losses serve as an important automatic fiscal stabilizer: more firms report losses during recessions and aggregate eligible refunds thereby increase (Altshuler et al., 2009). Policymakers also often expand refund generosity in bad times with the goal of injecting cash into the economy to promote business activity. Between 1998 and 2011, the loss offset provision made $\$ 357$ billion in refunds available, of which $\$ 124$ billion was available during the 2008-2009 recession. $^{2}$ Thus, whether firms claim eligible refunds is a question of policy and macroeconomic relevance.

The refund decision offers an attractive setting for studying the role of complexity in corporate behavior: a binary choice for which we can measure the payoffs of each option. Under corporate tax rules, a firm reporting a loss can choose between a carryback-in which the firm applies its loss against past taxable income and claims an immediate refund-and a carryforward -in which the firm reserves its loss to deduct against future income. The carryback is usually more valuable both because of discounting and because the firm risks losing its stock of carryforwards if it fails. Prior research has studied the impact of these rules on marginal tax rates, typically assuming that firms elect the carryback when available. ${ }^{3}$ This assumption delivers a strong null hypothesis that permits a test of costless optimizing behavior.

We explore the take-up of carryback refunds using a new dataset drawn from the population of U.S. corporate tax returns filed between 1998 and 2011. Our data consists of more than

\footnotetext{
${ }^{1}$ Recent reports from both the Bush and Obama administrations have made recommendations to reduce taxpayer burdens and improve tax administration by simplifying the tax code. See the "Comprehensive Strategy for Reducing the Tax Gap" (U.S. Treasury, 2006) and "The Report on Tax Reform Options: Simplification, Compliance, and Corporate Taxation" (The President's Economic Recovery Advisory Board, 2010). Both Congressman Paul Ryan's "A Better Way" and Senator Elizabeth Warren's "Leveling the Playing Field" policy platforms advocate reducing tax code complexity.

${ }^{2}$ This figure includes eligible refunds for all C corporations. We restrict our analysis to this corporate form because the treatment of losses takes place at the entity level. Losses for pass-through business entities, such as $S$ corporations and partnerships, are reported on the returns of their owners.

${ }^{3}$ See, for example, Auerbach and Poterba (1987), Altshuler and Auerbach (1990), and Graham (1996).
} 
1.2 million firm-year observations that are eligible for tax refunds. In addition to coverage, the dataset improves on past samples by enabling us to measure both eligible and actual refunds, to link firms to the tax preparers they hire to help them file their returns, and to explore interactions between the claiming decision and other provisions of the tax code.

The first part of the paper documents a key fact about claiming behavior: take-up is surprisingly low. Only 37 percent of eligible firms claim their refund. Low take-up holds even when we restrict our attention to potential refunds that are large relative to a firm's operating cash flows. Just half of the potential aggregate refund amount was claimed and distributed to eligible firms. Thus, the low take-up rate substantially limits the impact of this policy as fiscal stimulus.

We conduct a net present value (NPV) analysis of the carryback-carryforward trade-off to show that traditional costs and benefits, such as the direct cost of filing or the value of waiting, cannot explain the low take-up rate. For early years in our sample, we compute the ex post NPV of each option using a firm's realized path of taxable income over time. Most firms that fail to claim do not benefit from waiting, and many non-claimers forgo more than thirty percent of the refund's value. Our calculations assume conservative discount rates ranging from three to nine percent. If firms face financial frictions that generate higher discount rates, the net present value difference in favor of the carryback over the carryforward would be even greater. ${ }^{4}$

Our sampling frame is broad and representative of the full firm size distribution, which allows us to study the role of heterogeneous forces affecting small versus large firms. The median firm in our sample is small, with revenues of $\$ 1.5$ million and payroll of less than $\$ 500$ thousand. The largest firms in our sample are multinational public companies with billions of dollars of sales and thousands of employees. We find that small firms fail to claim refunds at higher rates than large firms and are more likely to forgo refunds with positive net present values. However, many large firms leave substantial refunds unclaimed, and the propensity to claim is non-monotonic in firm size, with the largest firms claiming less often than firms in the ninetieth percentile.

Motivated by these facts, the second part of the paper investigates the costs of complexity in driving average take-up behavior and patterns of take-up across the firm size distribution. It is likely that complexity distorts behavior in different ways for small firms than for large firms. Small firms may not know how to file for the carryback refund, or even that this option is available. Most small firms delegate tax code decisions to paid preparers. When monitoring is

\footnotetext{
${ }^{4}$ Zwick and Mahon (2017) find that firms only respond to investment tax incentives when they have an immediate impact on cash flows, suggesting that firms face financial frictions and evaluate tax benefits using high effective discount rates.
} 
imperfect, agency problems between managers and preparers can promulgate poor decisions, especially if there is dispersion in preparer quality. We evaluate this hypothesis by asking whether preparer characteristics can account for the variation in corporate claiming behavior. Our research design uses firms who switch tax preparers to identify the effect of preparers on client behavior, while controlling for time-invariant, firm-level unobservable factors. ${ }^{5}$

The main finding is that markers for preparer sophistication consistently predict take-up of the carryback refund. Preparers are more likely to claim the carryback refund when they are certified public accountants or attorneys, have higher earnings, do not work for themselves, are older, and have bigger client bases. These effects are quantitatively significant when compared to the mean take-up rate of 37 percent. Relative to preparers without a professional license, certified public accountants are 6.8 percentage points more likely to claim the carryback refund for their clients. Moving from the 10th to the 90th percentile in the size of a preparer's other clients increases take-up by 6.4 percentage points. Consistent with an interpretation that emphasizes preparer sophistication, preparer effects do not matter for the largest firms, who typically hire the most sophisticated preparers or build in-house tax departments.

The research design relies on the identifying assumption that changes in preparers are uncorrelated with unobservable changes in client determinants of take-up. Our estimates will be biased if hiring a more sophisticated manager leads to hiring a more sophisticated preparer and more sophisticated managers are more likely to claim refunds. We address this threat in two ways. First, we confirm the absence of differential trends in claiming rates prior to a preparer switch. Second, we validate our estimates in a sample of events when the prior preparer either dies or relocates, in which case it is more plausible that around the event client unobservables do not change. We find similar estimates as in our original design, indicating that selection bias does not confound our results.

Though preparer effects do not influence the claiming behavior of large firms, large firms are more likely to face other costs arising from the complexity of the tax code and how it is administered. First, interactions between the carryback and other tax code provisions may alter the cost-benefit calculation in favor of the carryforward, either by reducing the value of the carryback or by increasing the cost of filing a claim. Second, if a prior tax return is currently under audit, a taxpayer may choose to forgo the carryback to avoid interfering with the audit.

To explore these factors, we study how claiming behavior varies for firms subject to the

\footnotetext{
${ }^{5}$ The approach is analogous to that used to explore whether managerial "style" affects corporate decisions (Bertrand and Schoar, 2003; Kaplan, Klebanov and Sorensen, 2012), whether teachers affect student test scores (Jackson and Bruegmann, 2009), and whether firm effects contribute to wage inequality (Abowd, Kramarz and Margolis, 1999; Card, Heining and Kline, 2013).
} 
corporate alternative minimum tax (AMT) and for firms that claim alternative tax credits. Both sets of provisions primarily come into play for the largest firms in our sample and can generate significant interactions with carryback claims. We find that AMT payers are considerably less likely to claim a refund, and this gap in claiming rates is widest for firms at the top of the firm size distribution. For the top two percent of firms, the gap is approximately 20 percentage points, which suggests that AMT interactions may be a pivotal determinant of refund take-up among large firms. In contrast, among firms who claim other tax credits, we see consistently higher rates of carryback claims. We interpret this result as suggesting some complementarity in claiming complicated credits and claiming the carryback refund. Last, we present anecdotal evidence from public company financial statements, which suggests the audit compliance costs of claiming a refund may outweigh the benefits of immediate refunds for many firms.

This paper contributes to the literature on optimization frictions and behavioral responses to tax and public policy, which has mostly focused on settings where imperfect information or search costs weaken individual responses to taxes and public program take-up. ${ }^{6}$ These papers show that individuals under-respond to non-salient taxes (e.g., sales taxes, highway tolls, and the individual income tax) and often fail to take up social welfare programs (e.g., food stamps, job training programs, and public health insurance). Our results show that the tax code's complexity translates into suboptimal behavior and potentially significant costs for firms as well. An implication is that the classic focus on marginal tax rates may neglect important factors that mediate how firms respond to taxes.

Along with Kitchen and Knittel (2011), who document imperfect take-up of accelerated depreciation incentives, we present novel evidence of low take-up of tax refunds among firms. From the perspective of fiscal policy, our results suggest that complexity can undermine the design of tax-based fiscal stimulus, even when the policy setting is familiar and those targeted are relatively sophisticated. That many large firms also fail to claim tax refunds suggests this concern likely has aggregate implications. We show complexity alters corporate tax decisions in different ways for large versus small firms, which complements findings in Zwick and Mahon (2017) that heterogeneity within the population of firms matters for understanding tax policy responses.

\footnotetext{
${ }^{6}$ Key empirical studies on tax salience include Chetty, Looney and Kroft (2009), Finkelstein (2009), Chetty, Friedman and Saez (2013), Goldin and Homonoff (2013), and Bhargava and Manoli (2015). Abeler and Jäger (2015) use a lab experiment to show payoff schedule complexity directly interferes with optimal effort choices. The literature on public program take-up surveyed by Moffit (2003) and Currie (2006) emphasizes that low participation rates are due to filing requirements and poor information. See also Daponte and Taylor (1999), Currie and Grogger (2001), Bitler, Currie and Scholz (2003), Heckman and Smith (2004), Aizer (2007), Hoopes, Reck and Slemrod (2015), and the references therein.
} 
The paper also adds to a growing literature on the role of human capital in firm decision making. These studies have documented that firm investment, leverage, and effective tax rates depend on managerial style. ${ }^{7}$ We apply a novel research design using quasi-experimental tax preparer switches to show that, in addition to internal managers, external consultants can significantly affect how firms make decisions. Our results support the hypothesis in Romer (2006) that competition may not suffice to rid the market of suboptimal decision making among firms and the experts they hire to help them.

The paper proceeds as follows. Section 1 introduces the tax code's loss rules. Section 2 describes the corporate tax data and sample selection process. Section 3 documents refund take-up among eligible firms and performs a cost-benefit assessment of the tax loss choice, showing that the low take-up puzzle survives this analysis. Motivated by these findings, Section 4 asks whether tax code complexity can explain low take-up, explores the relationship between paid preparers and their clients' claiming patterns, and studies the interaction between refund claiming and other tax provisions. Section 5 discusses policy implications and future research directions.

\section{Policy Background}

Consider a firm that reports a tax loss. The corporate tax code allows the firm to apply losses in one year to offset profits in other years and thus reduce its average tax burden. The firm can choose either to carry the loss back against past taxable income or to carry the loss forward into the future. In tax code terminology, the option is between a carryback and a carryforward.

A statutory window limits the application of loss deductions to past and future tax years. Table 1 summarizes the statutory window for carrybacks and carryforwards in the U.S. tax code between 1998 and 2011. The carryforward window was twenty years throughout this time. The carryback window was mostly two years, except when Congress twice lengthened it to five years in response to recessions. These policy changes enhance the automatic stabilizer feature of the carryback provision, which generates more refunds in bad times when corporate losses are common.

\footnotetext{
${ }^{7}$ Bertrand and Schoar (2003) study the role of managers in corporate decision making. Bloom and Van Reenen (2007) and Kaplan, Klebanov and Sorensen (2012) document strong correlations between management practices and firm performance measures. Dyreng, Hanlon and Maydew (2010) and Armstrong, Blouin and Larcker (2012) show that managers influence corporate effective tax rates. Klassen, Lisowsky and Mescall (2016) find a crosssectional relationship between the aggressiveness of corporate tax positions and whether a firm's financial auditor prepares the tax return. Graham et al. (2017) find that many CFOs use theoretically incorrect tax rates when making decisions and that this behavior is correlated with behavioral biases and managers' education.
} 
The size of the refund generated by the carryback election depends on how much the firm has paid in past taxes. When a firm claims the carryback, it must fully apply the loss to all eligible past income. When the current loss exceeds eligible past income, a carryback generates both a refund for past taxes paid and a potential carryforward deduction equal to the losses in excess of past income. Loss firms without past income within the statutory window are not eligible for a carryback.

Table 2 uses a simple, numerical example to clarify the difference between the carryback and carryforward choices for a firm with a loss of $\$ 100$ at $t=0$. In each case, the loss generates deductions that the firm applies to offset taxable income in other years. If choosing the carryback, the firm first deducts its loss against taxable income at $t=-2$ and then deducts the remaining loss against taxable income at $t=-1$. Assuming a tax rate of 35 percent, the net present value of the carryback election equals $\$ 100 \times \tau$, or $\$ 35$.

If choosing the carryforward, the firm adds the loss to its stock of carryforwards and waits to deduct the loss. In the example, the firm does not have taxable income to offset at $t=1$ but can deduct all of its loss at $t=2$. The undiscounted value of this choice is the same as for the carryback. However, the deduction comes two years later. Continuing to assume a tax rate of 35 percent and applying a discount rate of 7 percent, the net present value of the carryforward election equals $\$ 100 \times \tau /(1+r)^{2}$, or $\$ 30.6$. In this example, the carryback election has a higher value because the tax rate is constant and the firm discounts future tax savings.

In theory, the economic consequences for the firm derive from differences in the tax benefit's timing. Under the carryback, firms immediately receive a refund for the taxes they paid in the past. Under the carryforward, firms defer the tax benefit until the future. The carryforward can be better if the firm expects to face a higher marginal tax rate in the future. For example, the corporate tax rate schedule is progressive for very low levels of income, so claiming a refund against this small amount might generate less savings than carrying the loss forward. Below, we show that this consideration is second order. Thus, in the traditional view of the tax loss choice, the carryback is typically more valuable for the simple reason that the firm values money now more than money later.

The traditional view however neglects the administrative differences involved in the tax loss choice. Claiming a carryforward is relatively straightforward. The firm must keep a record of its carryforward stock from past losses and then take a net operating loss deduction on its future tax return. The deduction is taken on the front page of the standard tax return after deductions for current business expenses and depreciation.

To claim a carryback, the firm must file a special form documenting how it computed its 
refund. The form details how the loss deduction is applied to past tax returns to generate a tax refund. ${ }^{8}$ This calculation essentially requires the firm to redo its past tax returns. The more complicated a firm's tax return is, the more likely this process is to trigger additional computations or offset past tax credits taken. Upon approving the firm's claim, the tax authority issues a refund equal to the amount of past overpaid taxes after accounting for the loss deduction. While the authority is not permitted to use the carryback claim to reopen a past tax return for other reasons, the authority may challenge the claim or seek adjustments. Thus, beyond the additional work required to file the carryback, the carryback is a more complex choice, as it entails interactions with prior tax planning decisions and possibly more scrutiny from the tax authority. This complexity may interfere with the firm's ability and desire to claim a refund.

Several studies consider how dynamic loss offsets alter effective tax rates and corporate behavior. Beginning with Cordes and Sheffrin (1983) and Auerbach and Poterba (1987), studies have attempted to quantify the effect of tax asymmetries on marginal tax rates, taking into account both carryforwards and carrybacks. ${ }^{9}$ Cummins, Hassett and Hubbard (1995) and Edgerton (2010) study the role of net operating loss carrybacks in mediating how investment responds to tax incentives. Dobridge (2017) and Bethmann, Jacob and Müller (2017) use policy variation to study the effect of net operating loss carrybacks on corporate investment, employment, and financial decisions. Data limitations have prevented these studies from testing the assumption that firms claim carrybacks when eligible.

\section{Data and Measurement}

\subsection{Business Tax Data}

We use de-identified, administrative IRS databases to study the tax loss choice and what factors influence a firm's decision to claim a carryback refund when eligible. These databases collect information for the population of corporations in the United States, approximately 5.9 million firms per year between 1998 and 2011. We rely on two main files: (1) a tax return file that

\footnotetext{
${ }^{8}$ A firm claims the carryback by filing either Form 1139 or Form 1120X. To remain eligible for the carryback, the firm must file within three years of the due date (plus extensions) of the tax return where it reports the loss. Alternatively, when filing its income tax return, the firm can elect to irrevocably forgo the carryback and fully carry forward the loss. This election is made by checking a box on the income tax return. All loss deductions against past and future taxable income are computed in nominal terms.

${ }^{9}$ Altshuler and Auerbach (1990) extend Auerbach and Poterba (1987) to model tax credit interactions. Graham (1996) develops a simulation methodology to derive the appropriate effective tax rates from financial accounting data. Plesko (2003) and Graham and Mills (2008) compare book simulated tax rates to tax rates derived from tax returns.
} 
records line items from corporate income tax returns, and (2) a transactions file that records debits and credits to individual tax accounts. We draw corporate characteristics from the tax return file and claimed refunds and tax adjustments from the transactions file. Characteristics for individual tax preparers come from a combination of individual tax returns and information returns for labor income reported on Forms W-2 and 1099-MISC. The IRS uses these databases to administer the corporate tax and to produce aggregate statistics used by other government agencies in policy analysis, revenue estimation, and economic measurement.

We limit our study to $\mathrm{C}$ corporations because they are taxed at the firm level and retain the decision over whether to claim the tax refund for losses. We exclude firms with mean sales and mean payroll over all active years between 1996 and 2011 of below \$100,000 because they may not represent operating firms (Knittel et al., 2011). To focus on firms with a meaningful carryback option, our main analysis sample includes firm-year observations that are eligible for a carryback refund of at least $\$ 1,000$. Our sampling frame is broader than in other recent papers working with administrative firm data in the U.S., which allows us to emphasize the role of heterogeneous forces affecting small versus large firms. ${ }^{10}$ We carefully partition the data to account for the skewness of the firm size distribution present in our sample.

Table 3(a) reports summary statistics for the sample of carryback eligible corporations, which consists of 1,244,729 firm-year observations for 612,070 distinct firms. Throughout the paper we report figures in 2013 dollar values. The median firm is small, with $\$ 1.5$ million in revenue, $\$ 489$ thousand in assets, and $\$ 469$ thousand in payroll. The eligible carryback refunds are also modest in size, with a median of approximately $\$ 5.7$ thousand. Among eligible firms, the median ratio of refund to revenue is 0.4 percent. For these firms the median ratio of earnings before interest, tax, and depreciation (EBITDA) to revenue is 4.6 percent. Thus, the median refund is modest but not negligible relative to a firm's earnings. We show below that focusing our analysis on a subsample with larger refunds does not affect the qualitative results.

Table 3 also includes variables for the tax preparer and tax firm matched to each corporate tax return. Most corporations hire small tax firms. The median corporation hires a tax firm with $\$ 785$ thousand in revenue and 98 corporate clients. The median tax preparer earns $\$ 99$ thousand in labor income and signs for 38 corporate clients. Roughly 16 percent of tax firms are unincorporated businesses, or sole proprietorships.

Table 3(b) reports summary statistics for a subset of firms that switch tax preparers between

\footnotetext{
${ }^{10}$ Yagan (2015) focuses on corporations with between $\$ 1$ million and $\$ 1$ billion in assets, and Zwick and Mahon (2017) focus on corporations with greater than $\$ 100,000$ in average investment during years of positive investment.
} 
1998 and 2011. All observations in this subsample match to a preparer. This subsample only includes two observations per firm: the last observation before switching preparers and the first observation after switching preparers. It consists of 124,862 firm-year observations for 62,431 individual firms. The firms in this sample look very similar on average to the full sample. The table also includes the preparer characteristics used to test whether client claiming behavior depends on which preparer is employed. Most tax preparers are certified public accountants (83 percent), but a non-negligible share report some other professional license (6 percent), a law degree ( 2 percent), or no license ( 9 percent). Approximately 18 percent of tax preparers are self-employed, as opposed to working at a tax firm.

Table 4 presents statistics for a size-based partition of the carryback sample. We divide the sample into ten deciles based on mean firm-level sales over all active years between 1996 and 2011. We then divide the top decile into five equal-sized bins to provide further detail on the right tail of the firm size distribution. Ninety percent of observations feature firm-years for relatively small firms, having mean sales between $\$ 340$ thousand and $\$ 8.7$ million. In contrast, mean sales among the top 2 percent of firms are $\$ 1.96$ billion. Considerable heterogeneity in the population implies that first-order factors affecting the tax loss choice for some firms may be irrelevant for others, a possibility that motivates our detailed analysis of various subpopulations.

\subsection{Measuring Carryback Eligibility}

The IRS databases do not explicitly record whether firms are eligible for a carryback, which requires us to simulate eligible refunds. Our algorithm proceeds as follows. First, we collect tax loss observations and for each observation the history of taxes paid in the years prior to the loss. We then adjust these past tax payments for various adjustments made in intervening years due to previously claimed carrybacks, the resolution of audits, and other amendments. We use the adjusted tax payments to impute past taxable income potentially eligible to be offset by the current loss. We apply the policy rules for the relevant year to determine the eligible carryback window. Starting with the earliest eligible year, we apply the current tax loss against imputed past taxable income. ${ }^{11}$ We continue with these deductions until either the current loss or past taxable income is exhausted. We then recompute the historical tax liability based on the postdeduction taxable income. The difference between the pre-deduction and post-deduction tax

\footnotetext{
${ }^{11}$ Tax losses are defined from the front page of the income tax return for $\mathrm{C}$ corporations. We use the statutory definition of tax losses for ordinary income, which equals net income (Line 28) plus special deductions (Line 29b). This definition excludes capital income losses. It also excludes losses obtained from mergers and acquisitions, which are reported with the stock of losses from prior periods (Schedule K, Line 12).
} 
liability provides our estimate for the eligible carryback refund.

We verify our algorithm for eligible refunds using firms that claim the carryback. For those firms that choose a carryback, we compare our simulated amount to the claimed amount. Our results indicate that we impute the eligible refunds with a high degree of accuracy. Regressing $\log$ (claimed amount) on $\log$ (eligible amount) yields a coefficient of 0.96 and an $\mathrm{R}^{2}$ of 0.93 . Appendix B provides more detail about how we construct and validate the eligible refund measure.

In computing eligible carrybacks, we do not make adjustments for the alternative minimum tax, nor do we track the foreign tax credit or various general business credits and their respective statutory windows. This simplification will affect the size of the estimated refund, but usually not whether a firm is eligible. Our results focus on the binary decision to claim the refund, which we measure well in cases where these features are relevant. In Section 4.2, we explicitly study these additional features of the code, which apply to a small but important set of companies and appear to interact with the carryback in influencing claiming behavior.

\section{Evidence on Tax Loss Choices}

\subsection{Low Take-up of Tax Refunds for Losses}

Figure 1 plots the total number of C-corporation, firm-year observations in total; the number that report a tax loss; the number that are eligible for a carryback refund; and the number that claim the carryback refund between 1998 and 2011. Taxable corporate losses are very common. Our sampling frame includes 12.1 million firm-year observations, of which 4.42 million experience a net operating loss. Eighty percent of firms experience a taxable loss at some point in time. Among these loss events, we identify 1.24 million, or 28 percent, as being eligible for a carryback refund of at least $\$ 1,000$. The reason all loss firms are not eligible for a refund is that a firm must have paid taxes in the past years within the statutory window. Still, firms frequently face the choice between applying a tax loss as a carryback or a carryforward.

Our first finding is that only 37 percent of eligible firms claim the refund. Because of low take-up, claimed refund amounts significantly understate the potential size of the policy. During the 1998-2011 period, C corporations were eligible for $\$ 357$ billion in carryback refunds yet claimed only $\$ 187$ billion. In 2008 and 2009 alone, they were eligible for $\$ 124$ billion yet claimed only $\$ 68$ billion. ${ }^{12}$ As a benchmark for the significant potential size of this pro-

\footnotetext{
${ }^{12}$ Using financial accounting data for public companies, Graham and Kim (2009) estimate potential refunds of approximately $\$ 131$ billion for tax years 2008 and 2009 (see Table 4, p.419). Possible differences between our
} 
gram, total payments for unemployment insurance were $\$ 209$ billion in 2008 and 2009 (U.S. Department of Labor, 2014). Thus, if policymakers intend for all eligible firms to claim a refund, low take-up may substantially undermine the potential effect of the carryback policy as a macroeconomically relevant fiscal stimulus.

Table 4 explores heterogeneity of low take-up across the firm size distribution. Moving from the bottom decile to the ninth decile, the average eligible refund ranges from $\$ 4.9$ thousand to $\$ 65$ thousand. In the tenth decile, eligible refunds range from $\$ 130$ thousand to $\$ 12.1$ million on average in the top group. These refunds are non-trivial as a share of firm cash flows for all groups and typically exceed estimates of the direct cost of preparing the carryback claim. At the same time, the refunds are not so large as to render implausible the notion that complexity might lead firms to ignore the carryback.

The table also reports claim rates and the frequency of eligible refunds for each size bin. Claim rates increase with firm size, rising from 31 percent in the lowest decile to 46 percent among the top 2 percent. On average, firms in our sample appear more than once, with this frequency increasing with firm size. Among firms appearing multiple times, fewer than one in five always claim a refund. This share varies little with firm size. In contrast, approximately half of the smallest firms never claim a refund, while just one in four of the largest firms never claim. Taken together, these patterns are consistent with a story where sophistication increases in firm size. Yet since the largest firms are not perfect claimers, limited knowhow is unlikely to explain low take-up among all firms. Table 4 highlights the importance of understanding the factors that drive the largest firms' behavior, as eligible refunds among the top 2 percent of firms amount to 84 percent of aggregate eligible refunds.

\subsection{A Net Present Value Analysis of Tax Loss Choices}

We begin our exploration of the factors driving low refund take-up with a simple net present value (NPV) analysis of the tax loss choice. This analysis compares the NPV of the carryback and carryforward options under various assumptions about the firm's path of future taxable income. This setting provides a rare opportunity to evaluate whether firms make the valuemaximizing choice from a binary set of options, in which the costs and benefits are relatively easy to measure. The nature of this exercise is therefore similar in spirit to Romer (2006), who uses the fourth down decision for football teams to explore firm maximization. Similar to his conclusion, our key finding is that low take-up cannot be justified for most firms within

estimates and theirs include our use of tax accounts, our exclusion of capital losses, and our inclusion of small and medium-sized firms. 
a simple cost-benefit framework, which motivates an exploration of additional costs owing to the complexity of the setting.

Loss firms deciding between the carryback and the carryforward elections need to consider whether it would be more valuable to use the loss as a deduction against past taxable income or against future taxable income. The carryback's value depends on the tax rates that the firm paid in the past. In contrast, the carryforward's value depends on the tax rates that it will pay in the future, the length of time that it will take the firm to return to a profitable state, and the firm's discount rate. These considerations also arise when the corporate loss exceeds eligible past taxable income because the carryback election generates a carryforward deduction equal to the loss in excess of eligible past income.

Computing the value of the carryback and carryforward elections involves an NPV calculation because either option can generate carryforward deductions to be applied against future taxable income. The key difference between their formulas is that the carryback election deducts the loss against past taxable income and the carryforward election does not. Carryback deductions against past taxable income are not discounted because they generate an immediate tax refund.

We formalize the NPV formulas for the carryback and carryforward elections under the assumption that the firm has perfect foresight over the timing of future taxable income,

$$
\mathrm{NPV}^{b}=\sum_{t=T_{\min }}^{-1} \tau_{t} D_{t}^{b}+\sum_{t=1}^{T_{\max }} \frac{\tau_{t} D_{t}^{b}}{(1+r)^{t}} \quad \mathrm{NPV}^{f}=\sum_{t=1}^{T_{\max }} \frac{\tau_{t} D_{t}^{f}}{(1+r)^{t}}
$$

where $\tau_{t}$ is the tax rate at time $t, D_{t}^{b}$ is the deduction taken at time $t$ under the carryback election, $D_{t}^{f}$ is the deduction taken at time $t$ under the carryforward election, $T_{\min }$ is the earliest tax year against which a carryback can be applied, $T_{\max }$ is the latest tax year against which a carryforward can be applied, and $r$ is the firm's discount rate for future tax savings. Time is indexed relative to the loss at $t=0$. Deductions applied to past taxable income are not discounted because the refund is immediate. In either case, the nominal sum of the deductions cannot exceed the loss reported at $t=0$. The nominal sum of the deductions can be less than the current loss in cases where the firm does not have sufficient past and future taxable income to offset the loss.

We empirically evaluate the NPV formulas in equation (1) for firms with losses between 1998 and 2002. We restrict our sample to this period because we want to use a future 10-year period of realized taxable income to value each firm's carryforwards. We assume that all firms in this period do not have any carryforwards from prior tax years. We make this assumption 
because the administrative tax data does not begin to collect this information until 2003. ${ }^{13}$ As above, we limit the sample to firms with eligible refunds of at least $\$ 1,000$ to exclude firms that do not have a meaningful carryback option.

We simulate the claiming of future carryforward deductions over a 10-year period based on firms' realized taxable income. We perform this simulation under both the carryback and carryforward elections. We assume firms will claim their future carryforward deductions as soon as possible and, in cases of surviving firms that have unused losses after 10 years, that all unused losses are claimed in the 11th year. This assumption raises the value of carryforwards relative to actual claiming behavior if some losses go unclaimed. We then compute the NPV of the carryback and carryforward elections using a discount rate of 7 percent. If firms use higher discount rates when evaluating this decision (Summers, 1987; Zwick and Mahon, 2017), this assumption will all also raise the value of carryforwards relative to their perceived value.

Figure 3(a) plots a histogram of the NPV difference between the carryback and carryforward elections, $\mathrm{NPV}^{b}-\mathrm{NPV}^{f}$. For 79 percent of the sample, the carryback election has a larger NPV than the carryforward. Thus, in the absence of other costs, most firms should value the carryback more than the carryforward. This finding would be even stronger and the NPV differences even larger under less conservative assumptions about how unused losses are claimed or about the discount rate firms use.

Figure 3(b) shows that this calculation may indeed understate the extent to which the carryback looks more appealing than the carryforward. This panel asks whether firms that do not elect the carryback immediately use most of the loss in future deductions. The sample is restricted from the sample in Figure 3(a) to those firms that do not claim a carryback refund. Over the ten years following the loss event, we plot mean cumulative carryforward deductions taken relative to the initial net operating loss. On average, firms capture just 50 cents of carryforward per dollar of loss by $t=2$. The level tapers off at approximately 75 cents per dollar at $t=6$. That some of the loss is never deducted reflects the possibility that firms often fail or do not return to positive tax position for many years. This finding is consistent with the facts in Cooper and Knittel $(2006,2010)$, who use corporate tax data to document incomplete utilization of net operating loss deductions. This fact significantly strengthens the appeal of the carryback option when it is available.

Do some firms show higher propensity to claim positive NPV refunds than others? Figure 4(a) shows how failure to claim positive NPV carrybacks varies across the firm size distribution within the NPV sample, and compares this to the share of refunds unclaimed for all eligible

\footnotetext{
${ }^{13}$ We find identical results when we replicate our analysis on firms with losses in 2003 where we do not need to make assumptions about their pre-existing stock of carryforwards.
} 
refunds in the full sample. Moving from the bottom decile to the ninth decile, the rate at which firms fail to claim positive NPV carrybacks falls with firm size, from 65 percent for the bottom decile to 25 percent around the ninetieth percentile. At this point, the pattern reverses, reaching 43 percent of positive NPV refunds unclaimed for the largest firms. The non-monotonic relationship between firm size and take-up propensity highlights the possible role of heterogeneous barriers to take-up.

Because claiming a carryback entails more paperwork, it is possible the direct filing cost exceeds the value of claiming. Conversations with preparers that serve small and mid-market firms suggest that filing for the carryback involves approximately two hours of additional work. The IRS estimates the average time to complete Form 1139 and claim a carryback is 16.5 hours, of which five hours entails learning about the form and presumably need not be paid for every claim. We use the preparers in our full sample to impute an hourly wage by dividing each individual preparer's annual labor income (including W-2 earnings and self-employment income) by 2,000 . The imputed wage at the 25 th, 50th, and 75th percentiles is approximately $\$ 20, \$ 45$, and $\$ 80$, respectively. This number is well below the average CPA billing rate of $\$ 180$ from the AICPA National MAP Survey, which likely reflects differences between the sample of surveyed CPAs and the full population of tax preparers. Combining these figures yields a range of potential cost estimates from roughly $\$ 40$ to $\$ 3,000$ for most firms. Even allowing for a markup for overhead expenses and profit, the value of the carryback exceeds these costs for most refunds in our sample. ${ }^{14}$

Figure 4(b) provides an alternative examination of whether a simple cost-benefit approach can explain claiming behavior. We plot the share of refunds unclaimed for all eligible refunds, for those refunds worth at least $\$ 10,000$, and for those refunds worth at least $\$ 100,000$. There are an insufficient number in the latter category for size bins below the fiftieth percentile. Refund size is strongly correlated with propensity to claim. However, many large refunds remain unclaimed. For the small and mid-market firms, approximately half of refunds with value greater than $\$ 10,000$ are unclaimed. Among larger firms, approximately one in four refunds exceeding $\$ 100,000$ is unclaimed. Among the largest firms, refund size is only weakly correlated with the take-up rate, partly because most refunds for these firms exceed $\$ 100,000$.

Taken together, the results suggest that while the value of waiting clearly plays a role in the take-up decision, the choice to forgo the carryback appears to fail a simple cost-benefit analysis. First, most firms appear to value the carryback more than the carryforward. Second, the money left on the table typically exceeds the estimated cost of claiming the refund. Third,

\footnotetext{
${ }^{14}$ We thank Erin Towery for providing data on hours from the IRS and CPA billing rates.
} 
small firms fail to claim refunds at higher rates than large firms and are more likely to forgo refunds with positive NPVs. Fourth, many large firms leave substantial refunds unclaimed, and the propensity to claim is non-monotonic in firm size, with the largest firms claiming less often than firms in the ninetieth percentile. The last two facts motivate an investigation of the costs of complexity in driving average take-up behavior and patterns of take-up across the firm size distribution.

\section{Can Tax Code Complexity Explain Low Take-up?}

In 2006, the U.S. Department of the Treasury's Office of Tax Policy conducted a study to develop a "comprehensive strategy" for reducing the gap between taxes owed and taxes paid. The report offers an assessment of the current system and a call to simplify it, stating bluntly "[the] current tax code is too complicated." The deleterious effects of this complexity include making the law "too difficult for taxpayers to understand and for the IRS to administer," leading to "unintentional errors," providing new "opportunities for those who are willing to exploit the system," while making it "difficult for the IRS to detect noncompliance." The report presages some of our findings with regard to fiscal policy:

limited IRS resources are increasingly committed to administering a wide array of targeted tax provisions created to meet social policy goals. These targeted provisions, which themselves are growing increasingly complicated, divert IRS resources from basic compliance efforts (U.S. Department of the Treasury, Office of Tax Policy, 2006, p. 15).

In this section, we present direct evidence of the role of tax code complexity in driving the low take-up of carryback refunds. Based on a simple cost-benefit analysis, most firms should claim the carryback. Our goal is to explore several channels where our data permit an evaluation of how complexity can alter this calculation. For small firms, we focus on the relationship between firms and the experts they hire to prepare their taxes. Tax code complexity may amplify agency problems if principals cannot perfectly monitor their agents because they do not understand the code. For large firms, we focus on compliance costs associated with the interaction between carryback claims and other tax code provisions or existing audits of past tax returns. 


\subsection{Small Firms and the Agency Costs of Complexity}

Most small firms delegate tax code decisions to paid preparers. Tax preparers inform their clients about the tax code, file tax returns on their clients' behalf, and warn clients about the audit risk of different tax reporting choices. Preparers may differ in whether they encourage their clients to claim the tax refund based on their own beliefs about its merits for their clients, its filings costs, and its audit risks. When monitoring is imperfect, agency problems between managers and preparers can promulgate poor decisions, especially if there is dispersion in preparer quality. In this section, we provide evidence that client take-up of the carryback refund depends on preparers in a way consistent with the prediction that complexity undermines the tax loss choice.

The Market for Corporate Tax Preparation Services. A large private market provides tax preparation services to firms. In 2011, 96 percent of corporations hired an external preparer to file their income taxes. The market comprised 188 thousand individual preparers who file tax returns for corporations. Although federal regulations do not mandate licensing requirements for preparers, 89 percent of firms hired a preparer with a professional license (mainly certified public accountants). ${ }^{15}$ The remaining 11 percent of firms hired preparers without any professional credentials.

Table 4 shows that dependence on an external preparer is nearly universal across the firm size distribution in our sample. In the bottom decile, 93 percent of firms rely on an external preparer. The share increases to 96 percent for firms above median size. Only among the very largest firms do we see a switch to internal preparers, with 79 percent of the top two percent of firms using external preparers. For this reason, we later examine how the role of paid preparers in client decisions varies at the top of the firm size distribution.

The tax preparation market includes a wide variety of tax firms. They range from sole proprietorships with a single employee to national brands with thousands of locations. These firms also vary in their degree of specialization. Some focus on tax preparation (e.g., H\&R Block, Inc.) whereas others offer a broad portfolio of professional services for businesses (e.g., BDO USA, LLP). At most tax firms, employees use tax preparation software to manage client returns (Internal Revenue Service, 2009). Conversations with mid-market preparers suggest this software does not fully automate the process of claiming a carryback.

\footnotetext{
${ }^{15}$ Either a certified public accountant, attorney, enrolled agent, or state licensed preparer. Enrolled agents are licensed by the Internal Revenue Service. They must pass an examination and fulfill 72 hours of continuing education every three years.
} 
Contracts between external preparers and their clients offer relatively low-powered incentives for preparers to minimize their clients' tax burdens. Incentive fees are explicitly prohibited by law. ${ }^{16}$ Preparers instead bill their clients by the hour or by the tax form. Thus, the return to the preparer of making the right choice is largely independent of the value of that choice to the client. Against this flat incentive to claim a carryback, firms face the risk that a refund claim will increase the likelihood of IRS audit. When a firm applies for the carryback, the IRS reviews the recomputed tax liability for prior years. This review carries the risk that the IRS will spot something that will prompt an audit. Legally, the IRS cannot use such a review to open claims that exceed the value of the refund. However, the perceived risk of audit may be sufficient to deter claiming a carryback.

Claiming Decisions and Preparer Characteristics. We use firms that switch preparers to show that preparer characteristics predict claiming behavior. Starting with all firms that were eligible for carryback refunds of at least \$1,000 between 1998 and 2011, we restrict the sample to firms that were eligible in multiple years and that switched preparers. For each firm, we include the last observation before and the first observation after switching preparers. These observations are often not consecutive because firms are usually not eligible for the carryback refund in multiple consecutive tax years. If a firm changes preparers multiple times, we only include observations associated with the last switching event.

We begin with a simple graphical illustration of the role of preparer effects in driving refund claims. Figure 5 plots within-firm covariances of carryback take-up conditional on a set of client and refund observables, including indicators for deciles of eligible carryback refund, revenue, assets, and payroll; state-year and industry-year fixed effects; and firm fixed effects. We separate observation pairs based on the length of time between observations and whether the observations share the same preparer. Three facts emerge. First, covariances are consistently higher for pairs where the firm has the same preparer. Second, the difference in covariance is stable over time between observations, consistent with the preparer effect being a timeinvariant attribute of the preparer. Third, the difference in covariances (approximately 2.5 percent) is quantitatively relevant. As a benchmark, client and refund observables account for roughly 9 percent of the variance in claiming.

We exploit rich data on preparer characteristics to investigate the factors driving these pre-

\footnotetext{
${ }^{16}$ Title 31 "Regulations Governing Practice before the Internal Revenue Service" in Treasury Department Circular No. 230 states: “(a) In general. A practitioner may not charge an unconscionable fee in connection with any matter before the Internal Revenue Service. (b) Contingent fees- (1) Except [in audit, challenge, or judicial proceeding], a practitioner may not charge a contingent fee for services rendered in connection with any matter before the Internal Revenue Service."
} 
parer effects. Our main specification is a panel regression given by

$$
\mathrm{I}(\text { carryback take-up })_{i j t}=Z_{\mathbf{J}(i, t)} \gamma+X_{i t} \beta+\alpha_{i}+\delta_{t}+\epsilon_{i t} \text {, }
$$

where the subscripts represent client $i$ with preparer $j$ in tax year $t, Z_{\mathbf{J}(i, t)}$ are preparer characteristics, $X_{i t}$ are client characteristics, $\alpha_{i}$ is the client fixed effect, and $\delta_{t}$ is the tax-year fixed effect. Preparer observables include indicators for professional credentials, $\log$ (labor income), I(self-employment), age, $\log$ (mean client revenue), and $\log$ (total client revenue). Client observables include $\log$ (revenue) and $\log$ (assets). ${ }^{17}$

The research design is analogous to strategies used by Bertrand and Schoar (2003) to estimate the effects of CEO style on firm performance and Card, Heining and Kline (2013) to estimate how dispersion in the firm component of pay contributes to wage inequality. These switching designs rely on the identifying assumption that client unobservables in the error term are uncorrelated with preparer characteristics conditional on client observables, a client fixed effect, and a tax-year fixed effect. Because the switchers design uses within-firm variation, this assumption holds if unobservable determinants of carryback take-up do not change before and after switching preparers. We validate this assumption using pre-trend tests and a subsample of plausibly exogenous switching events.

Table 5(a) reports estimates from equation (2) for the full sample of switching events. The regressions in columns (1) through (5) are univariate with respect to preparer characteristics. Column (6) presents a multivariate specification. All regressions include a firm fixed effect, a tax-year fixed effect, and firm controls. They also include dummies for missing values of the preparer characteristics and the client controls. We cluster standard errors at the firm level.

The main finding is that markers for preparer sophistication consistently predict take-up of the carryback refund. Preparers are more likely to claim the carryback refund when they are certified public accountants or attorneys, are better paid, do not work for themselves, are older, and have bigger client bases. Except for age effects, we can consistently reject the null of zero effect in the univariate regressions. These effects also retain their statistical significance in the multivariate specification, and the effect for age is stronger and statistically significant in this case.

These effects are quantitatively significant when compared to the mean take-up rate of 37 percent. Relative to preparers without a professional license, certified public accountants are

\footnotetext{
${ }^{17}$ We include separate indicators for certified public accountants, attorneys, and preparers with another professional license. The last category includes enrolled agents and state licensed preparers. The omitted category are preparers without any professional credential. The self-employment indicator equals one if the preparer derives at least half of their labor income from self-employment.
} 
6.8 percentage points more likely to claim the carryback refund for their clients. Similarly, attorneys are 4.7 percentage points more likely to claim. Moving from the 10th to the 90th percentile in $\log$ (labor income) increases take-up by 1.9 percentage points $(=(12.51-9.98) \times$ .0074). Moving from the 10th to the 90th percentile in $\log$ (mean client revenue) increases take-up by 6.4 percentage points $(=(16.62-13.06) \times .0179)$. The effects of age are smaller, with an increase of roughly 0.3 percentage points for each additional decade. Taken together, the results indicate a substantial effect of preparers on client behavior.

How plausible is it that preparers differ markedly in sophistication? Further evidence comes from two Government Accountability Office (GAO) studies of paid preparers. In these studies, the GAO sent field examiners to have individual tax returns prepared and then investigate whether preparers were making consistent and legal recommendations to their clients. The GAO documented serious errors and inconsistencies across preparers, in some cases within the same tax firm. These reports prompted a broader review of paid preparers by the IRS and eventually led to the launch of a 120-question basic competency test required for noncredentialed preparers. ${ }^{18}$ In a field experiment providing information to Earned Income Tax Credit (EITC) applicants, Chetty and Saez (2013) document heterogeneous treatment effects by tax preparer and argue these effects derive from differences in preparers' understanding of the code. Furthermore, in a separate study of EITC take-up among individuals, Bhargava and Manoli (2015) report conversations with practitioners who suggest the "sheer size of the preparer population and the ease of application... has led to significant variation in preparer quality," which may contribute to low take-up rates of complex credits.

While these studies focus on individual tax returns, it is plausible that similar dispersion in tax code knowledge and practice exists among preparers filing corporate tax returns, especially among small firms. One prediction of the sophistication hypothesis is that preparer effects should be less important for larger firms, either because these firms are able to monitor preparers more effectively or because these firms hire from the pool of skilled experts.

We test this by running separate switcher analyses within each firm size decile as defined in Table 4. Specifically, we implement the multivariate regression from column (6) of Table 5(a) and conduct F-tests for the joint significance of the preparer characteristics. Within the bottom nine deciles, average F-statistics vary from 1.56 to 4.67, which correspond to a p-value range of 0.15 to 0.00 . In the tenth decile, the F-statistic is 0.89 with a p-value of 0.51 . Thus, consistent with a preparer sophistication interpretation of the results, for all but the largest

\footnotetext{
${ }^{18}$ The studies are GAO-06-563T and GAO-14-467T, both titled "Paid Tax Return Preparers: In a Limited Study, Chain Preparers Made Serious Errors" (Government Accountability Office, 2006, 2014). IRS regulation of the paid preparer industry has been challenged in federal court and remains an area of active legal and policy concern.
} 
firms we can reject the hypothesis that preparers are irrelevant for the take-up decision.

Robustness. A common validation for an event study design plots trends before and after the event in a balanced panel. This placebo test evaluates whether a spurious effect appears in periods without treatment. To implement this test, we focus on a subsample of events where we have four observations per firm: two observations before changing preparers and two observations after changing preparers.

For each firm, we order observations by tax year and define them relative to the first observation after the firm changes preparers. We restrict the sample to a balanced panel, as changes in the sample over time can introduce spurious trends. We call this order event time $e$ where $e \in\{-2,-1,0,1\}$. We then construct a measure of the treatment effect associated with each event from the multivariate estimates from column (6) of Table 5(a): $\Delta \widehat{\mu}_{\mathbf{J}(i, 0)}=Z_{\mathrm{J}(i, 0)} \widehat{\gamma}-Z_{\mathrm{J}(i,-1)} \widehat{\gamma}$. We then estimate a variant of our baseline panel regression where we allow the coefficient $\theta_{e}$ on the treatment effect $\Delta \widehat{\mu}_{J(i, 0)}$ to vary with event time:

$$
\mathrm{I}(\text { carryback take-up })_{i j t}=\Delta \widehat{\mu}_{\mathrm{J}(i, 0)} \theta_{e}+X_{i t} \beta+\alpha_{i}+\delta_{t}+\zeta_{e}+v_{i t} .
$$

The regression equation above also includes client characteristics $X_{i t}$, a client fixed effect $\alpha_{i}$, a tax-year fixed effect $\delta_{t}$, and an event time fixed effect $\zeta_{e}$. We omit a dummy for the event time $e=-2$ to avoid collinearity, so coefficients $\theta_{e}$ are estimated relative to the coefficient at event time $e=-2$.

Estimating equation (3) tests for pre-trends and post-trends that are correlated with the preparer effect $\Delta \widehat{\mu}_{\mathrm{J}(i, 0)}$. The key test is whether predicted effects are zero in the carrybackeligible year prior to the switch (i.e., at $e=-1$ ). On average, the coefficient after the switch $\theta_{0}$ should equal one because the client has changed preparers, and take-up reflects the change in the predicted preparer effect. We should also expect $\theta_{1}$ to equal one because most clients are with the same preparer at event time $e=1$. If the sample for this test were the same as for the full sample, then $\theta_{0}$ will equal one by construction. However, no mechanical restrictions apply to $\theta_{-1}$ and $\theta_{1}$ because the baseline regression excludes observations from event time $e=-2$ and event time $e=1$.

Figure 6 plots estimates of the coefficients $\theta_{e}$. The regression includes dummies for missing values of the preparer characteristics and the client controls. We cluster standard errors at the firm level. We cannot reject the null of zero for the coefficient $\theta_{-1}$ and find point estimates close to one for both $\theta_{0}$ and $\theta_{1}$. The results strongly validate our research design, confirming the absence of both pre-trends and post-trends that are correlated with the treatment effect. 
Preparer Deaths and Relocations. Our estimates of equation (2) rely on the identifying assumption that unobservable determinants of client take-up remain unchanged before and after switching preparers. But clients may change preparers in response to a change in their firm. For example, a client may hire a new preparer when it hires a new manager. The change in client unobservables that cause the firm to switch preparers could also affect its claiming behavior. Here, we focus on a subsample of events where the prior preparer either dies or relocates to a new zip code at least 75 miles away. In these cases, it is more plausible that client unobservables remain unchanged around the switching event.

We identify deaths and relocations by linking preparers to a social security file and to their individual income tax returns. We compute the distance between personal residence addresses based on the centroids of their zip codes before and after a relocation. We then identify firms that change preparers contemporaneously with either the death or relocation of the prior preparer. The sample includes 4,912 death or mover events.

Table 5(b) reports results from estimating equation (2) for this subset of events. We estimate regressions separately for each preparer characteristic, and we also include the predicted preparer effect based on column (6) of Table 5(a) as an additional covariate. All regressions include a client fixed effect, a tax year fixed effect, and firm controls.

The estimates are broadly similar to our earlier results. With the exception of the covariates I(other professional license), which has a stronger effect than in the full sample, and I(selfemployment), which has a different sign but loses statistical significance, we find coefficients close to our earlier point estimates. As the sample falls from 124,862 to 9,824 observations, these tests have less statistical power to detect effects, but we still find strongly significant results for I(certified public accountant) and $\log$ (mean client revenue). And, we estimate a strongly significant coefficient of 0.9372 on the predicted preparer effect. This last result implies that the switchers design estimates an unbiased preparer effect. Together, our estimates indicate that changes in client unobservables do not confound the original results from the switchers design.

We focus on deaths and relocations because we believe it is more likely that client unobservables remain unchanged before and after the switching event. But selection could still arise in this subsample from the hiring of new preparers. Our results could be confounded if the same client unobservables that determine preparer hiring also determine take-up of the carryback refund.

We address this additional concern with a two-stage least squares estimate with the deaths and relocations subsample. Intuitively, we instrument for the change in the preparer effect 
with the prior preparer characteristic because we think that the change in client unobservables is unrelated to the prior preparer. To clarify the interpretation of our identifying assumption, we express our estimates for this design in a first-differences version of equation (2):

$$
\Delta \mathrm{I}(\text { carryback take-up })_{i j e}=\Delta Z_{\mathrm{J}(i, e)} \gamma+\Delta X_{i e} \beta+\Delta \delta_{\mathrm{T}(i, e)}+\Delta \epsilon_{i e}
$$

As above, we index observations by event time $e .^{19}$ The difference is taken between the first observation after the switching event and the last observation before the event, which are not always consecutive as firms are not eligible for the carryback refund in every year.

To instrument for the change in the preparer effect $\Delta Z_{\mathrm{J}(i, e)}$, we use the difference between the sample mean preparer effect and the predicted effect for the preparer prior to the switch, $\Delta \widetilde{Z}_{\mathrm{J}(i, e)}=\bar{Z}-Z_{\mathrm{J}(i, e-1)}$. The two-stage least squares estimates identify the causal treatment effect of preparer covariates under the assumption that the change in client unobservables is uncorrelated with the characteristics of the prior preparer (as represented by the instrument $\left.\Delta \widetilde{Z}_{\mathrm{J}(i, e)}\right)$, the change in client observables, and the tax-year fixed effects. If changes in client unobservables do not correlate with preparer deaths and relocation, then this assumption is likely to hold.

Table 6 reports two-stage least squares estimates for regressions with client fixed effects and different control sets. Column (2) adds a tax-year fixed effect. Column (3) adds firm controls. As discussed above, the predicted preparer effect captures the estimated relationship between preparer characteristics and carryback take-up, which implies an expected coefficient of one. Consistent with this prediction, the regressions yield point estimates of 1.18, 1.00, and 0.75 in columns (1), (2), and (3). The confidence intervals are relatively large, but in all specifications we can reject the null of a zero coefficient at a 5 percent level and cannot reject the hypothesis that the coefficients equal one. These results further validate the predicted preparer effect estimated under the switchers design.

\subsection{Large Firms and the Compliance Costs of Complexity}

Because large firms are more sophisticated in developing their own tax planning strategies, they may be less subject to agency problems between the firm and hired experts. However, large firms are more likely to face other costs arising from the complexity of the tax code and how it is administered. In this section, we consider two potential factors. First, interactions between the carryback and other tax code provisions may alter the cost-benefit calculation in

\footnotetext{
${ }^{19}$ The function $\mathbf{T}(i, e)$ maps firm $i$ at event time $e$ to tax year $t$.
} 
favor of the carryforward, either by reducing the value of the carryback or by increasing the cost of filing a claim. Second, if a prior tax return is currently under audit, a taxpayer may choose to forgo the carryback to avoid interfering with the audit. Even if these considerations only apply to a small share of firms, these costs may prove critical for designing policy that uses the code to promote social priorities because the largest firms account for the majority of dollars at stake.

Interactions with Other Tax Code Provisions. We separately analyze two sets of tax code provisions that generate additional complexity through interactions with carrybacks: (1) the corporate alternative minimum tax (AMT) and (2) a basket of tax credits and offset provisions. Both the AMT and tax credits contribute significantly to estimated costs of tax return filing and estimated time to prepare a corporate tax return, making them likely to contribute to the complexity of a large corporation's tax return. These provisions apply after the firm computes taxable income but before the firm computes total tax, thus interacting with loss offsets after economic costs have been taken into account. Claiming a carryback requires a firm to recompute its AMT liability and eligibility for tax credits claimed in the past, thus increasing the cost of claiming and possibly reducing the size of a refund.

Figure 7(a) documents carryback claiming behavior by firm size, while separating firms that have never paid the AMT from firms that have paid the AMT at some time. The statistic above the bars reports the share of observations in that size bin that have paid the AMT at some time. Two facts emerge. First, the AMT is not relevant for most firms in the economy. Less than ten percent of firms in the bottom five deciles ever pay AMT. For these firms, interactions with the AMT are unlikely to explain low refund take-up. In contrast, more than half the firms in the top decile pay some corporate AMT, with this figure reaching 77 percent for the top two percent of firms. Second, in terms of carryback take-up, we see that AMT payers are considerably less likely to claim a refund, and this gap in claiming rates is widest for firms at the top of the firm size distribution. For the top two percent of firms, the gap is approximately 20 percentage points, which suggests that AMT interactions may be a pivotal determinant of refund take-up among large firms. ${ }^{20}$

Figure 7(b) plots the share of refunds unclaimed for firms that have never claimed other tax credits and for firms that have claimed other tax credits at some time. The statistic above the bars reports the share of observations in that size bin that have never claimed other tax credits.

\footnotetext{
${ }^{20}$ One potential explanation for this fact is that net operating losses can only be used to offset ninety percent of AMT income, which can reduce the value of a refund. Unfortunately, our data do not permit us to decompose post-adjustment tax liabilities into regular and AMT liability. We thank Andrew Lyon for this suggestion.
} 
We consider all credits claimed on Form 1120, Schedule J, Line 5, including the foreign tax credit and all credits from the general business credit claimed on Form 3800. In 2016, the general business credit included 37 different credits, the majority of which are claimed via distinct forms and apply to highly specialized activities (e.g., the Mine Rescue Team Training credit or the Distilled Spirits credit). Appendix D lists these credits and provides short descriptions.

As for the AMT, only in the top few deciles of the firm size distribution do we see a significant share of firms claiming other tax credits. Less than ten percent of firms in the bottom five deciles ever claim these other credits. Thus, interactions with other provisions are unlikely to explain low take-up for these firms. In contrast, two-thirds of firms in the top two percent claim other credits. Among firms who do claim other credits, we see consistently higher rates of carryback claims. The effects are smaller than for the AMT but remain notable.

This finding contrasts with the pattern for AMT payers, who showed lower rates of carryback claiming. We interpret these results as suggesting some complementarity in claiming complicated credits and claiming the carryback refund. One policy implication of this finding is that the incidence of carryback expansions may fall on firms that have invested in more sophisticated tax planning operations. It is unclear whether policymakers intend to target these firms when pursuing fiscal stimulus through these provisions.

Anecdotal Evidence of Corporate Tax Complexity. As a final piece of evidence that complements our administrative data, we turn to public company filings to ask how firms talk about their burden as taxpayers when communicating with shareholders. Using only data from Compustat, we identify a set of firms that are likely to have had carryback opportunities during the 2009 recession. These firms report large financial losses in 2009 and large cumulative profits over the prior five years. ${ }^{21}$ We hand collect quotes from annual filings that describe their tax positions with respect to net operating losses. To protect taxpayer confidentiality, we cannot link these statements to our administrative data set.

The first quote comes from Rite-Aid's 10-K filing:

The federal income tax returns are closed to examination by the Internal Revenue Service (IRS) through fiscal 2005. However, any net operating losses that were generated in these prior closed years may be subject to examination by the IRS upon utilization...Additionally the IRS completed the examination of the consolidated U.S. income tax return for Brooks Eckerd for the fiscal years 2004 and 2005. A revenue agent report (RAR) was received in the fourth quarter of fiscal

\footnotetext{
${ }^{21}$ The sample selection begins with all Compustat filings for the years 2004-2009 for firms incorporated in the U.S. We then restrict to firms with income before extraordinary items (Compustat item IB) less than \$-100M in 2009 and total taxes paid (Compustat item TXT) in 2004, 2005, and 2006 exceeding \$100M.
} 
2010. The company is appealing these audit results...State income tax returns are generally subject to examination for a period of three to five years after filing of the respective return. However, as a result of reporting IRS audit adjustments, the Company has statutes open in some states from fiscal 2003. (emphasis added)

This example highlights three key points. First, federal tax returns for the largest companies are audited every year and often remain open to examination and negotiation for many years. Here, Rite-Aid reports in 2009 having tax returns open back to 2006 for federal purposes and to 2003 for state tax purposes. Second, the concluding position of these audits is often contested. Companies frequently appeal audit results in order to claim disallowed deductions or propose alternative interpretations of the code. Third, if the use of a net operating loss either for carryforward or carryback triggers an adjustment on a closed return, the IRS may reopen that return to evaluate the net operating loss claim. Relative to carryforwards, carryback claims are more likely to interfere with ongoing audits, since they entail amendments to past returns. Such interference may considerably amplify the cost of claiming a carryback for large firms.

The second quote comes from Marriott's 10-K filing:

We filed a refund claim relating to 2000 and 2001. The IRS disallowed the claims, and in July 2009, we protested the disallowance. This issue is pending in the IRS Appeals Division.

This example illustrates that a carryback claim can take years to be resolved. Conversations with former tax accountants suggest such cases are rare but possible. Presumably the cost of legal and accounting services needed to protest disallowed claims would prevent a firm from pursuing small refunds. The example also highlights the uncertainty that taxpayers and accountants may face when filing for a refund.

The third quote comes from Chesapeake's 10-K filing:

At December 31, 2009, Chesapeake had federal income tax net operating loss (NOL) carryforwards and carrybacks of approximately \$889 million and \$681 million, respectively. Additionally, we had $\$ 3$ million of alternative minimum tax (AMT) NOL carryforwards available as a deduction against future AMT income and $\$ 333$ million of AMT NOL carrybacks to be used against prior year AMT income. The NOL carryforwards expire from 2019 through 2029. The value of these carryforwards depends on the ability of Chesapeake to generate taxable income. (emphasis added)

This example shows the added complexity created by the corporate AMT, which requires firms to keep separate accounts for regular tax and AMT, including accounting for accumulated stocks of carryforwards and potential carrybacks. The filing does not report whether Chesapeake in 
fact claimed the carrybacks. The quote also shows that firms recognize that carryforwards can expire unclaimed and advise investors to account for this possibility in valuing deferred tax assets.

The last quote comes from Applied Materials's 10-K filing:

During fiscal 2010, Applied received a U.S. federal income tax refund of approximately \$130 million for the carryback of Applied's net operating loss from fiscal 2009 to fiscal 2005. (emphasis added)

Indeed, some firms did benefit from the extended carryback window and claimed substantial refunds. During the most severe disruption in financial markets since the Great Depression, this program provided Applied Materials with a large liquidity infusion. The example thus highlights the potential for this stimulus program to support the economy in times of economic weakness and points to why reforms that enable more eligible firms to benefit may be desirable.

The anecdotes presented in this section provide context for the literature that has shown carryback incentives can explain reporting and operating behavior for public companies. Maydew (1997) finds that the Tax Reform Act of 1986 induced firms to shift income intertemporally to generate larger carryback refunds. Erickson, Heitzman and Zhang (2013) expand this idea to document refund-motivated income shifting in a sample of companies between 1981 and 2010. While these studies observe heterogeneous patterns across firms due to potential refund size and the presence of financial constraints, differences in tax compliance costs may also affect income shifting.

\section{Conclusion}

The most direct finding of our work is that the assumption that firms always claim refunds for tax losses does not fit the data. This departure is quantitatively relevant and suggests that additional costs of claiming refunds mute the potential impact of carryback extensions as fiscal stimulus. Fiscal stimulus measures often rely on the introduction of new and temporary tax benefits. For example, the American Reinvestment and Recovery Act of 2009 distributed 36 percent of its stimulus dollars through 55 different tax benefits (The Recovery Accountability and Transparency Board, 2014). Our results underscore the importance of careful, transparent design of fiscal policy, even when the policy setting is familiar and even when those targeted are sophisticated.

More broadly, our results show that corporate tax decisions reflect the complexity of the tax code in addition to the simple costs and benefits of individual provisions and in contrast to the 
classic focus on marginal tax rates. Tax code complexity factors into corporate decision-making in different ways for small firms versus large firms. For small firms, complexity can amplify agency frictions between firms and the experts they hire to help them file their tax returns. For large firms, complexity emerges from interactions with other tax code provisions and with the compliance process, leading to claiming behavior that departs significantly from predictions considering individual policies in isolation.

Our study highlights the mediating role that preparers play between the tax code and taxpayers by showing that preparers influence tax claiming decisions. The results suggest that investing in better take-up of tax benefits could be as important as adding new targeted provisions. Future research might consider whether targeting preparers with informational materials or training or providing taxpayers with automatic defaults can improve the take-up of corporate tax benefits.

Our research has several limitations. First, we focus primarily on one policy and thus cannot speak directly to whether these considerations prove critical in other settings. Second, measuring the effects of complexity is inherently difficult. Our approach offers an incomplete look into how complexity can affect behavior, but necessarily restricts to channels which permit direct measurement and analysis. Last, we are not directly measuring the real effects of failure to claim a tax refund, so some caution is warranted in drawing conclusions about whether complexity affects other firm outcomes. 


\section{References}

Abeler, Johannes, and Simon Jäger. 2015. "Complex Tax Incentives." American Economic Journal: Economic Policy, 7(3): 1-28.

Abowd, John M., Francis Kramarz, and David N. Margolis. 1999. "High Wage Workers and High Wage Firms." Econometrica, 67(2): 251-333.

Aizer, Anna. 2007. "Public Health Insurance, Program Take-up, and Child Health." Review of Economics and Statistics, 89(3): 400-415.

Altshuler, Rosanne, Alan Auerbach, Michael Cooper, and Matthew Knittel. 2009. "Understanding U.S. Corporate Tax Losses." Tax Policy and the Economy, 23: 73-122.

Altshuler, Rosanne, and Alan J. Auerbach. 1990. "The Significance of Tax Law Asymmetries: An Empirical Investigation." Quarterly Journal of Economics, 105(1): 61-86.

Armstrong, Chris, Jennifer L. Blouin, and David F. Larcker. 2012. "The Incentives for Tax Planning." Journal of Accounting and Economics, 53(1-2): 391-411.

Auerbach, Alan J., and James M. Poterba. 1987. "Tax-Loss Carryforwards and Corporate Tax Incentives." In The Effects of Taxation on Capital Accumulation. Vol. I, 305-342.

Bertrand, Marianne, and Antoinette Schoar. 2003. "Managing with Style: The Effect of Managers on Firm Policies." Quarterly Journal of Economics, 118(4): 1169-1208.

Bethmann, Inga, Martin Jacob, and Maximilian Müller. 2017. "Tax Loss Carrybacks: Investment Stimulus versus Misallocation." FAccT Center Working Paper.

Bhargava, Saurabh, and Dayanand Manoli. 2015. "Psychological Frictions and the Incomplete Take-Up of Social Benefits: Evidence from an IRS Field Experiment." American Economic Review, 105(11): 3489-3529.

Bitler, Marianne P., Janet Currie, and John Karl Scholz. 2003. "WIC Eligibility and Participation." Journal of Human Resources, 38: 1139-1179.

Bloom, Nicholas, and John Van Reenen. 2007. "Measuring and Explaining Management Practices Across Firms and Countries." Quarterly Journal of Economics, 122(4): 1351-1408.

Card, David, Jörg Heining, and Patrick Kline. 2013. "Workplace Heterogeneity and the Rise of West German Wage Inequality." Quarterly Journal of Economics, 128(3): 967-1015.

Chetty, Raj, Adam Looney, and Kory Kroft. 2009. "Salience and Taxation: Theory and Evidence." American Economic Review, 99(4): 1145-1177.

Chetty, Raj, and Emmanuel Saez. 2013. "Teaching the Tax Code: Earnings Responses to an Experiment with EITC Recipients." American Economic Journal: Applied Economics, 5(1): 131. 
Chetty, Raj, John Friedman, and Emmanuel Saez. 2013. "Using Differences in Knowledge Across Neighborhoods to Uncover the Impacts of the EITC on Earnings." American Economic Review, 103(7): 2683-2721.

Cooper, Michael, and Matthew Knittel. 2006. "Partial loss refundability: How are corporate tax losses used?" National Tax Journal, 651-663.

Cooper, Michael, and Matthew Knittel. 2010. "The Implications of Tax Asymmetries for U.S. Corporations." National Tax Journal, 63(1): 33-63.

Cordes, Joseph J., and Steven M. Sheffrin. 1983. "Estimating the tax advantage of corporate debt." Journal of Finance, 38(1): 95-105.

Cummins, Jason G., Kevin A. Hassett, and R. Glenn Hubbard. 1995. "Have Tax Reforms Affected Investment?" In Tax Policy and the Economy, Volume 9. 131-150. MIT Press.

Currie, Janet. 2006. "The Take Up of Social Benefits." In Public Policy and the Income Distribution., ed. Alan J. Auerbach, David Card and John M. Quigley. Russell Sage Foundation Publications.

Currie, Janet, and Jeffrey Grogger. 2001. "Explaining Recent Declines in Food Stamp Program Participation." Brookings-Wharton Papers on Urban Affairs, 203-244.

Daponte, Beth Osborne, Sanders Seth, and Lowell Taylor. 1999. "Why Do Low-Income Households not Use Food Stamps? Evidence from an Experiment." Journal of Human Resources, 34(3): 612-628.

Dobridge, Christine L. 2017. "Fiscal stimulus and firms: A tale of two recessions." Working paper.

Dyreng, Scott D., Michelle Hanlon, and Edward L. Maydew. 2010. "The Effects of Executives on Corporate Tax Avoidance." The Accounting Review, 85(4): 1163-1189.

Edgerton, Jesse. 2010. "Investment Incentives and Corporate Tax Asymmetries." Journal of Public Economics, 94(11-12): 936-952.

Erickson, Merle M., Shane M. Heitzman, and X. Frank Zhang. 2013. "Tax-Motivated Loss Shifting." The Accounting Review, 88(5): 1657-1682.

Finkelstein, Amy. 2009. "EZ-Tax: Tax Salience and Tax Rates.” Quarterly Journal of Economics, 124(3): 969-1010.

Goldin, Jacob, and Tatiana Homonoff. 2013. "Smoke Gets in Your Eyes: Cigarette Tax Salience and Regressivity." American Economic Journal: Economic Policy, 5(1): 302-336.

Government Accountability Office. 2006. "Paid Tax Return Preparers: In a Limited Study, Chain Preparers Made Serious Errors." GAO-06-563T.

Government Accountability Office. 2014. "Paid Tax Return Preparers: In a Limited Study, Chain Preparers Made Serious Errors." GAO-14-467T. 
Graham, John R. 1996. "Debt and the Marginal Tax Rate." Journal of Financial Economics, 41(1): 41-73.

Graham, John R., and Hyunseob Kim. 2009. "The Effects of the Length of the Tax-Loss Carryback Period on Tax Receipts and Corporate Marginal Tax Rates." National Tax Journal, 62(3): 413.

Graham, John R., and Lillian F. Mills. 2008. "Using tax return data to simulate corporate marginal tax rates." Journal of Accounting \& Economics, 46(2-3): 366-388.

Graham, John R., Michelle Hanlon, Terry Shevlin, and Nemit Shroff. 2017. "Tax Rates and Corporate Decision-Making." Review of Financial Studies, 30(9): 3128-3175.

Heckman, James J., and Jeffrey A. Smith. 2004. "The Determinants of Participation in a Social Program: Evidence from a Prototypical Job Training Prorgam." Journal of Labor Economics, 22(2): 243-298.

Hoopes, Jeffrey L., Daniel H. Reck, and Joel Slemrod. 2015. "Taxpayer Search for Information: Implications for Rational Attention." American Economic Journal: Economic Policy, 7(3): 177-208.

Internal Revenue Service. 2009. "Return Preparer Review.” Publication 4832 (Rev. 12-2009) Catalog Number 54419P.

Jackson, C. Kirabo, and Elias Bruegmann. 2009. "Teaching Students and Teaching Each Other: The Importance of Peer Learning for Teachers." American Economic Journal: Applied Economics, 1(4): 85-108.

Kaplan, Steven N., Mark M. Klebanov, and Morten Sorensen. 2012. "Which CEO Characteristics Matter?" Journal of Finance, 67(3): 973-1007.

Kitchen, John, and Matthew Knittel. 2011. "Business Use of Special Provisions for Accelerated Deprecition: Section 179 Expensing and Bonus Deprecition, 2002-2009.” Working paper.

Klassen, Kenneth, Petro Lisowsky, and Devan Mescall. 2016. "The Role of Auditors, NonAuditors, and Internal Tax Departments in Corporate Tax Aggressiveness." The Accounting Review, 91(1): 179-205.

Knittel, Matthew, Susan Nelson, Jason Debacker, John Kitchen, James Pearce, and Richard Prisinzano. 2011. "Methodology to Identify Small Businesses and Their Owners." OTA Working Paper.

Maydew, Edward L. 1997. "Tax-Induced Earnings Management by Firms with Net Operating Losses." Journal of Accounting Research, 83-96.

Moffit, Robert A., ed. 2003. Means-Tested Transfer Programs in the United States. University of Chicago Press. 
Plesko, George A. 2003. "An evaluation of alternative measures of corporate tax rates." Journal of Accounting and Economics, 35(2): 201-226.

Romer, David. 2006. "Do Firms Maximize? Evidence from Professional Football." Journal of Political Economy, 114(2): 340-365.

Summers, Lawrence H. 1987. "Investment Incentives and the Discounting of Depreciation Allowances." In The Effects of Taxation on Capital Accumulation. 295-304. University of Chicago Press.

The President's Economic Recovery Advisory Board. 2010. "The Report on Tax Reform Options: Simplification, Compliance, and Corporate Taxation."

The Recovery Accountability and Transparency Board. 2014. "Overview of Funding."

U.S. Department of Labor, Employment \& Training Administration. 2014. "Unemployment Insurance Data."

U.S. Department of the Treasury, Office of Tax Policy. 2006. "A Comprehensive Strategy for Reducing the Tax Gap."

Yagan, Danny. 2015. "Capital Tax Reform and the Real Economy: The Effects of the 2003 Dividend Tax Cut." American Economic Review, 105(12): 3531-3563.

Zwick, Eric, and James Mahon. 2017. "Tax Policy and Heterogeneous Investment Behavior." American Economic Review, 107(1): 217-48. 
Figure 1: Carryback Eligibility and Take-up (Population, 1998-2011)

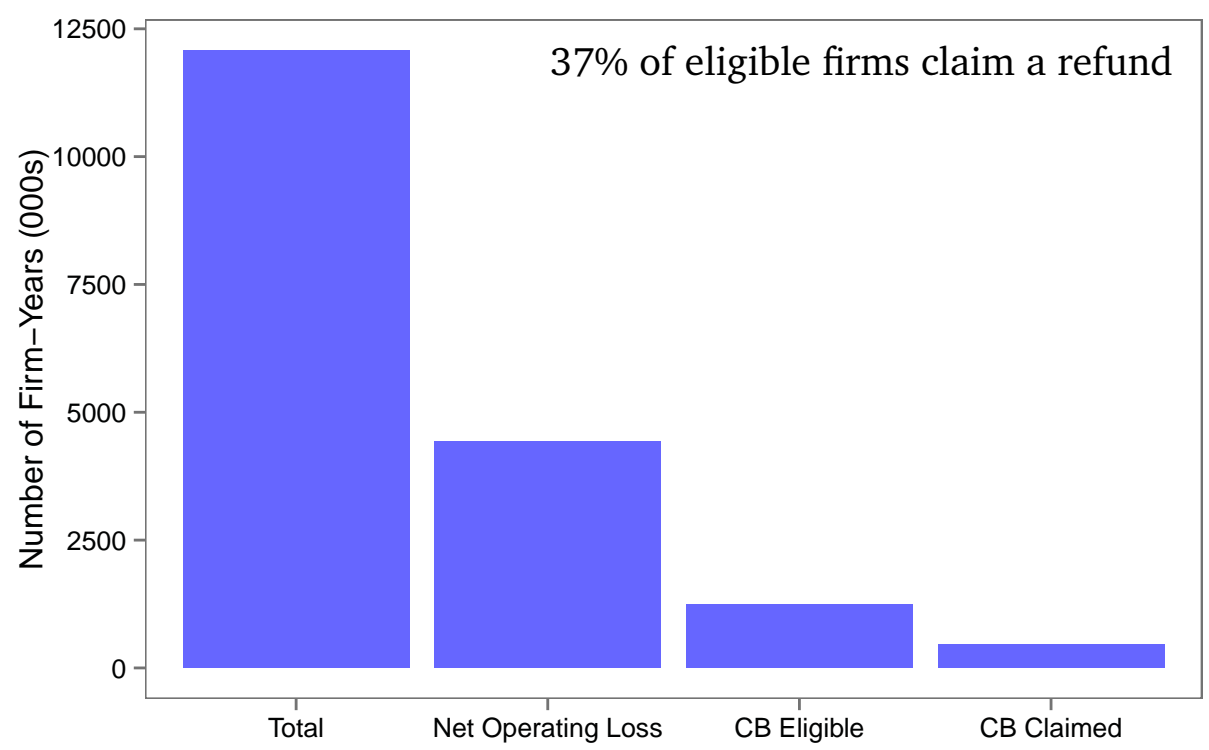

Notes: This figure plots (1) the total number of C-corporation, firm-year observations in total, (2) the number that report a tax loss, (3) the number that are eligible for a carryback refund, and (4) the number that claim the carryback refund, respectively. We limit eligibility to firms that have the option to claim a carryback refund of at least $\$ 1,000$. We exclude firms with mean revenue and mean payroll less than $\$ 100,000$. All dollar amounts are indexed to 2013 price levels. 
Figure 2: Aggregate Carryback Take-up Statistics by Year (Population, 1998-2011)

(a) Frequency of Carryback Refunds

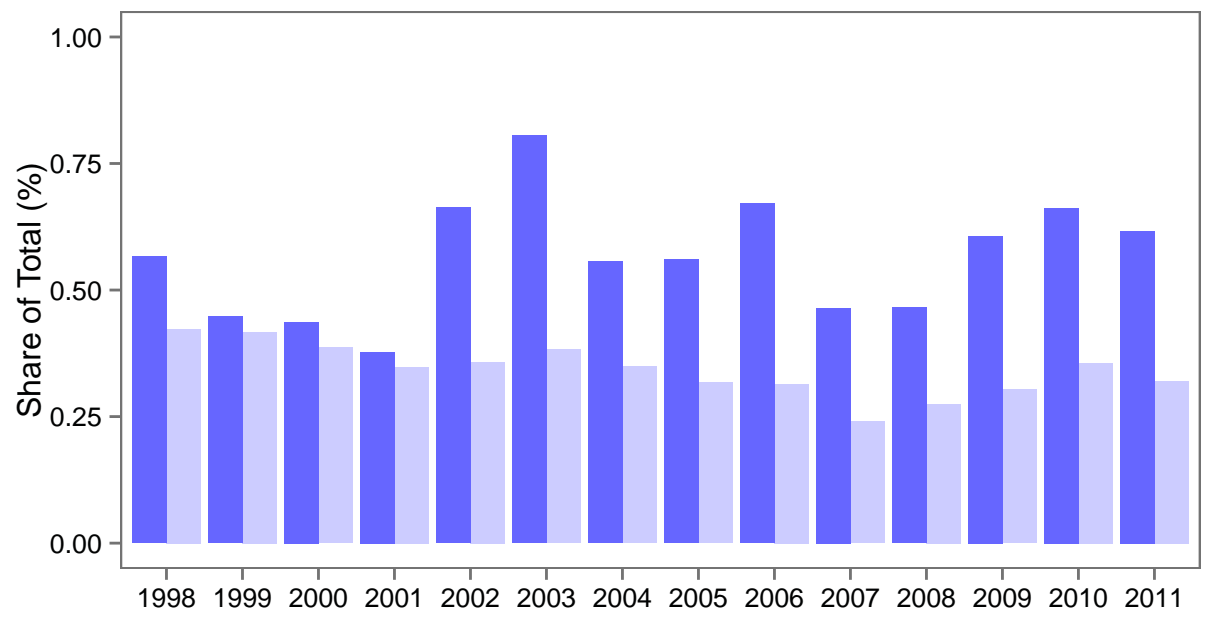

Dollars Claimed Number Claimed

(b) Aggregate Eligible and Claimed Refunds

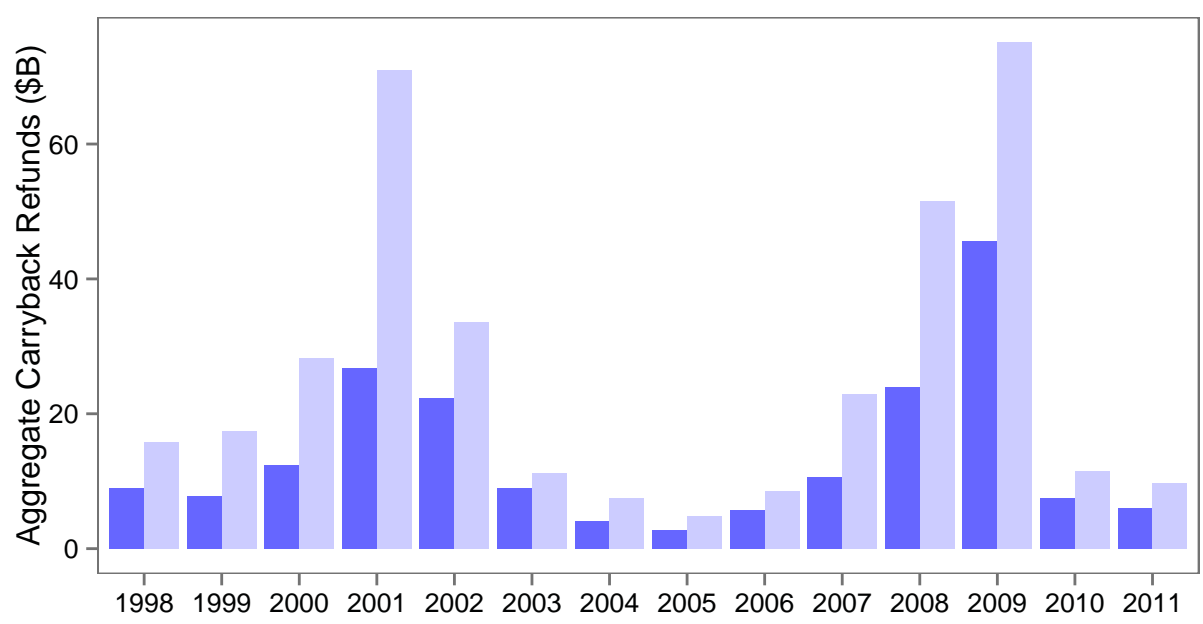

Actual Refunds Simulated Refunds

Notes: This figure plots the incidence of carryback refund eligibility and claiming behavior over time. Panel (a) plots the share of total dollars claimed and the share of eligible refunds claimed each year. Panel (b) plots aggregate dollar amounts of eligible and claimed refunds. We limit eligibility to firms that have the option to claim a carryback refund of at least $\$ 1,000$. We exclude firms with mean revenue and mean payroll less than $\$ 100,000$. All dollar amounts are indexed to 2013 price levels. 
Figure 3: Comparing the Value of Carrybacks and Carryforwards (NPV Sample, 1998-2002)

(a) Histogram of NPV Difference between Carryback and Carryforward

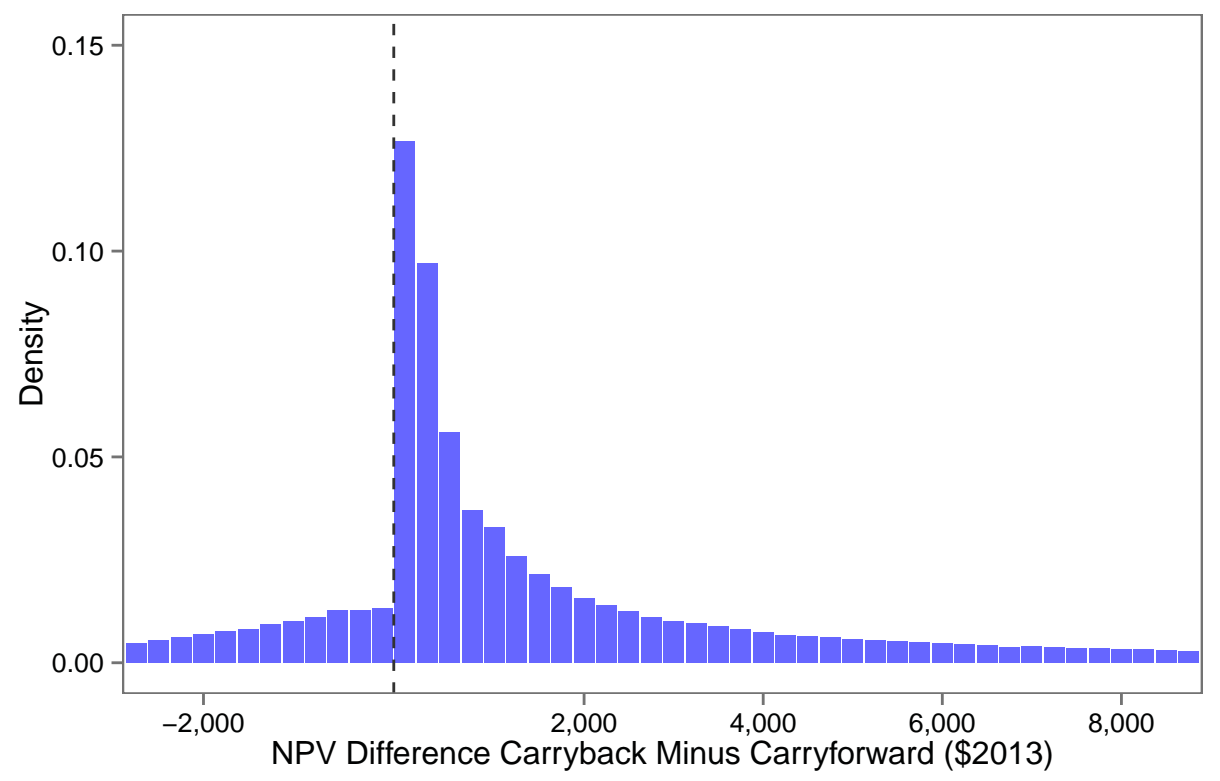

(b) Undiscounted Carryforwards by Carryback-Eligible Non-Claimers

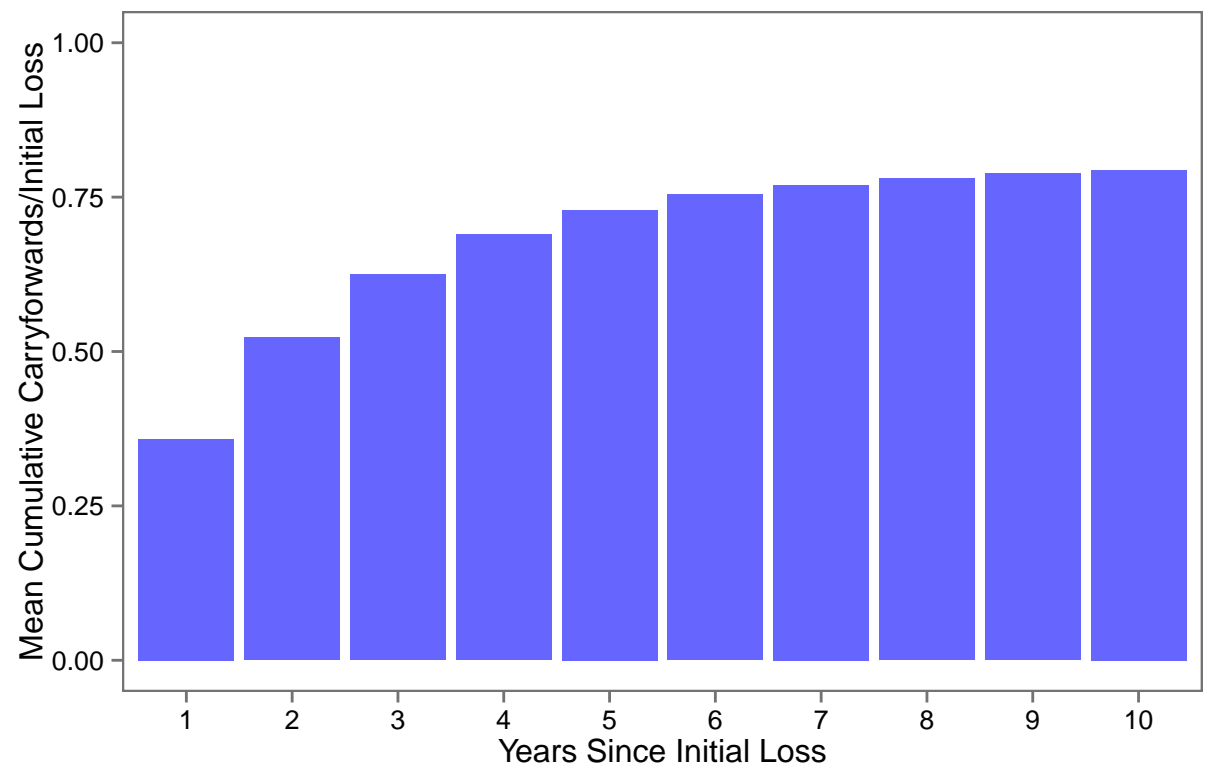

Notes: This figure provides information about the relative value of carrybacks and carryforwards for a sample of eligible firms for which we have ten years of data following the loss event. Panel (a) plots a histogram of the net present value difference between the carryback and carryforward elections. We calculate the net present value based on each firm's realized taxable income over a 10-year period. We use realized taxable income to simulate the claiming of future carryforward deductions and to compute the net present value of future tax benefits. The sample includes firms with tax losses between 1998 and 2002 that were eligible for a carryback refund of at least $\$ 1,000$. Panel (b) plots mean cumulative carryforward deductions taken relative to the initial loss over the ten years following the loss event. The sample is restricted from the sample in Panel (a) to those firms that do not claim a carryback refund. 
Figure 4: Characteristics of Unclaimed Refunds

(a) Unclaimed Refunds versus Firm Size and Refund NPV (NPV Sample, 1998-2002)

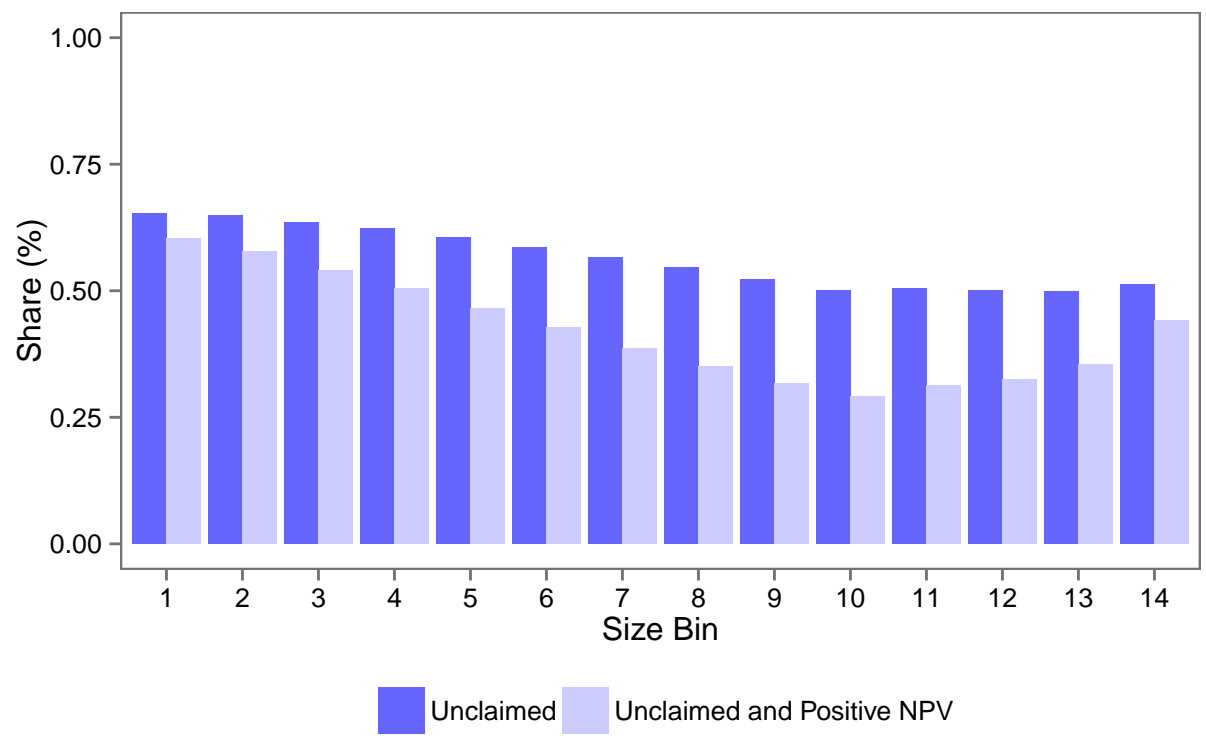

(b) Unclaimed Refunds versus Refund Size (Population, 1998-2011)

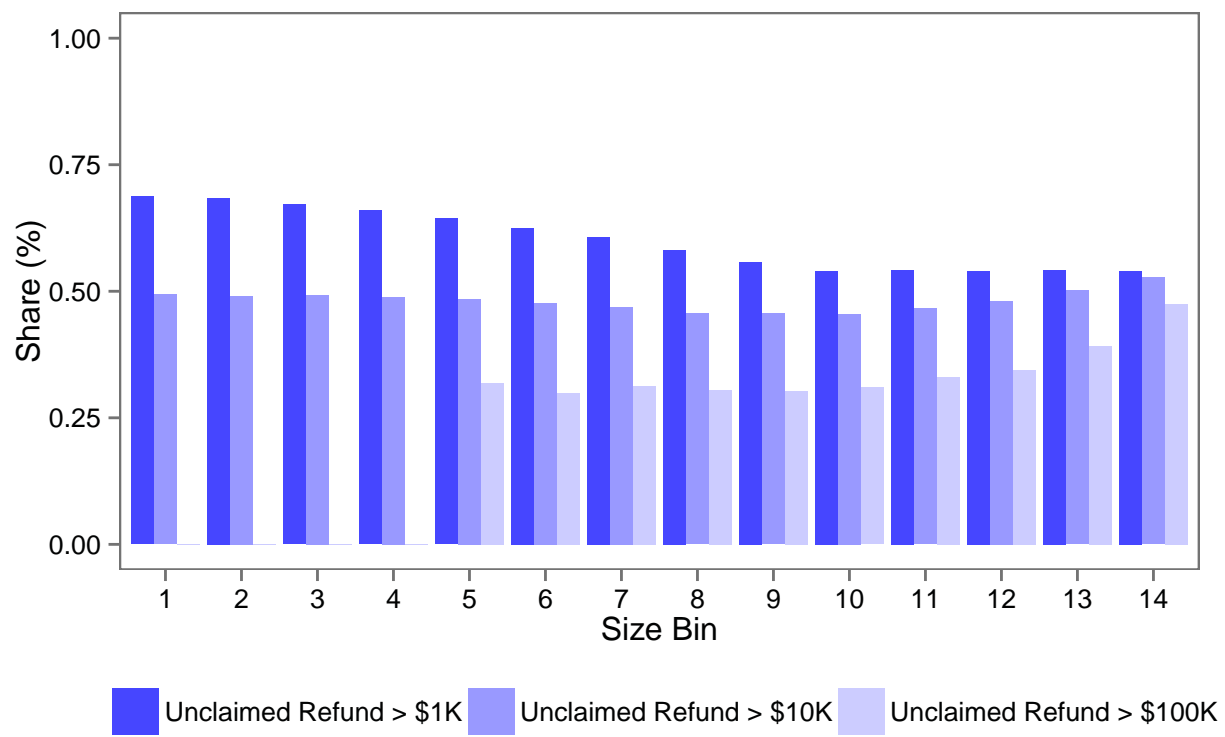

Notes: This figure documents carryback claiming behavior by firm size, refund NPV, and refund size. Panel (a) plots the share of refunds unclaimed for all eligible refunds and for a restricted sample of refunds where the net present value difference between the carryback and carryforward elections favors claiming the refund. The sample includes firms with tax losses between 1998 and 2002 that were eligible for a carryback refund of at least $\$ 1,000$. Panel (b) plots the share of refunds unclaimed for all eligible refunds, for those refunds worth at least $\$ 10,000$, and for those refunds worth at least $\$ 100,000$. There are an insufficient number in the latter category for size bins 1 through 4 . The sample includes firms that have the option to claim a carryback refund between 1998 and 2011. We exclude firms with mean revenue and mean payroll less than $\$ 100,000$. All dollar amounts are indexed to 2013 price levels. Size bins 1 through 9 demarcate the first nine deciles of the main analysis sample firm size distribution in mean sales. Size bins 10 through 14 divide the tenth decile into 2-percent bins. 
Figure 5: Preparers and the Persistence of Carryback Claims (Switcher Sample, 1998-2011)

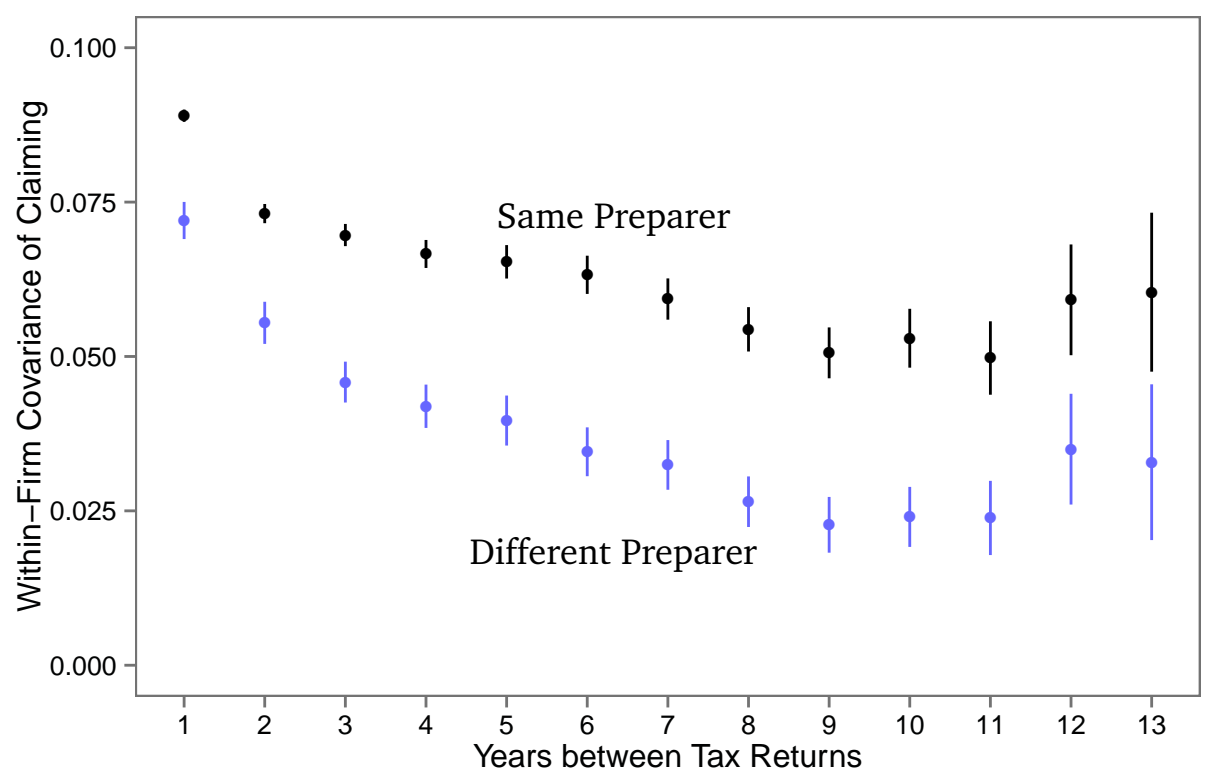

Notes: This figure reports the within-firm covariances of residual carryback take-up. Standard errors are block bootstrapped with 1,000 replications. The estimates are based on the residual $T_{i j t}=$ I(carryback take-up) $W_{i t} \pi$ where $W_{i t}$ are client observables. The coefficients $\pi$ are estimated from a regression of take-up on client observables and a preparer fixed effect. Client observables include deciles in the eligible carryback refund, deciles in revenue, deciles in assets, deciles in payroll, state-year fixed effects, and industry-year fixed effects. We estimate covariances for pairs of observations from the same firm. We differentiate between pairs by the length of time between observations and by whether the observations share the same preparer. 
Figure 6: Carryback Claims and Predicted Preparer Effects (Switcher Sample, 1998-2011)

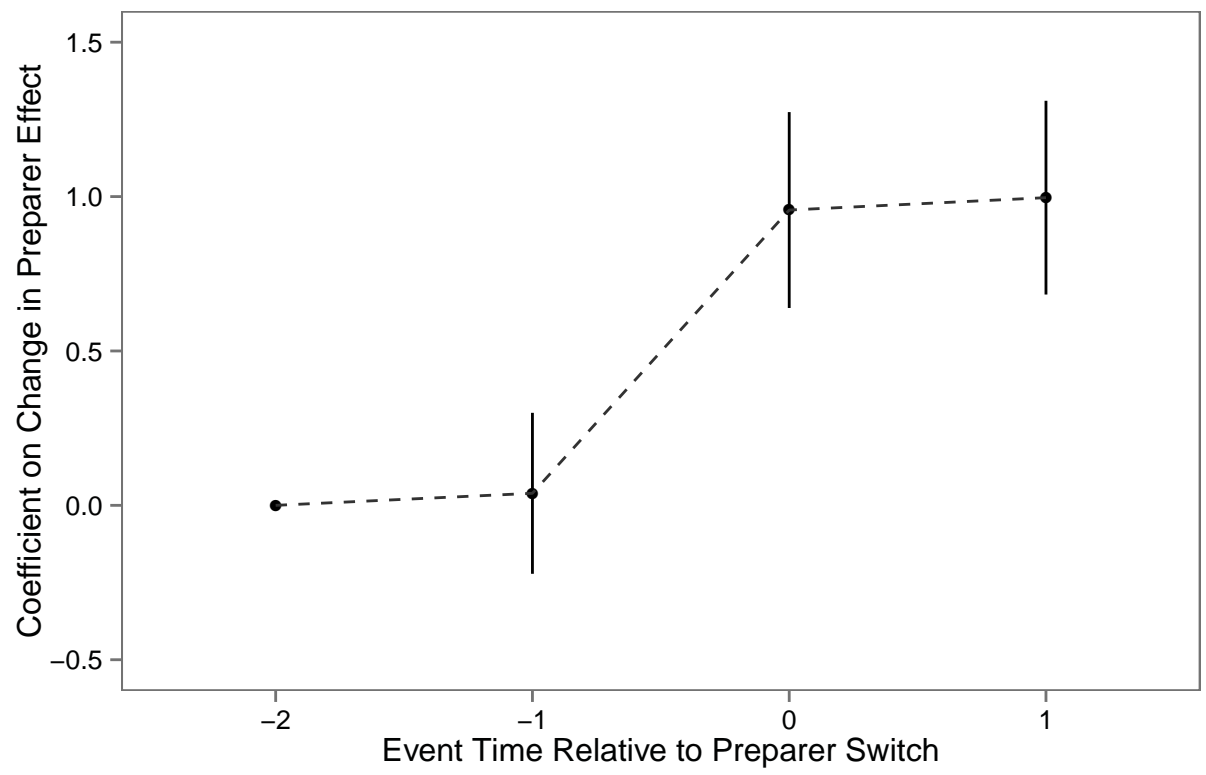

Notes: This figure plots the coefficients from a regression of carryback take-up on interactions between event time and the change in the predicted preparer effect at event time $e=0$. We construct the predicted preparer effects using the estimated coefficients from Column (6), Panel (a) of Table 5. The change in the predicted preparer effect at event time $e=0$ equals $\Delta \widehat{\mu}_{\mathrm{J}(i, 0)}=Z_{\mathrm{J}(i, 0)} \widehat{\gamma}-Z_{\mathrm{J}(i,-1)} \widehat{\gamma}$. The regression includes a firm fixed effect, a tax-year fixed effect, firm controls, and an event-time fixed effect. Firm controls include log(eligible refund), $\log$ (revenue), $\log$ (assets), and $\log$ (EBITDA). The regression also includes dummies for missing values in firm controls. The regression omits a dummy for event time $e=-2$ to avoid collinearity. The plotted coefficients are estimated relative to event time $e=-2$. The coefficient at event time $e=-2$ equals zero by construction. Standard errors are clustered at the firm level. 
Figure 7: Unclaimed Refunds and Tax Return Complexity (Population, 1998-2011)

(a) Claim Rates for Alternative Minimum Tax (AMT) Payers

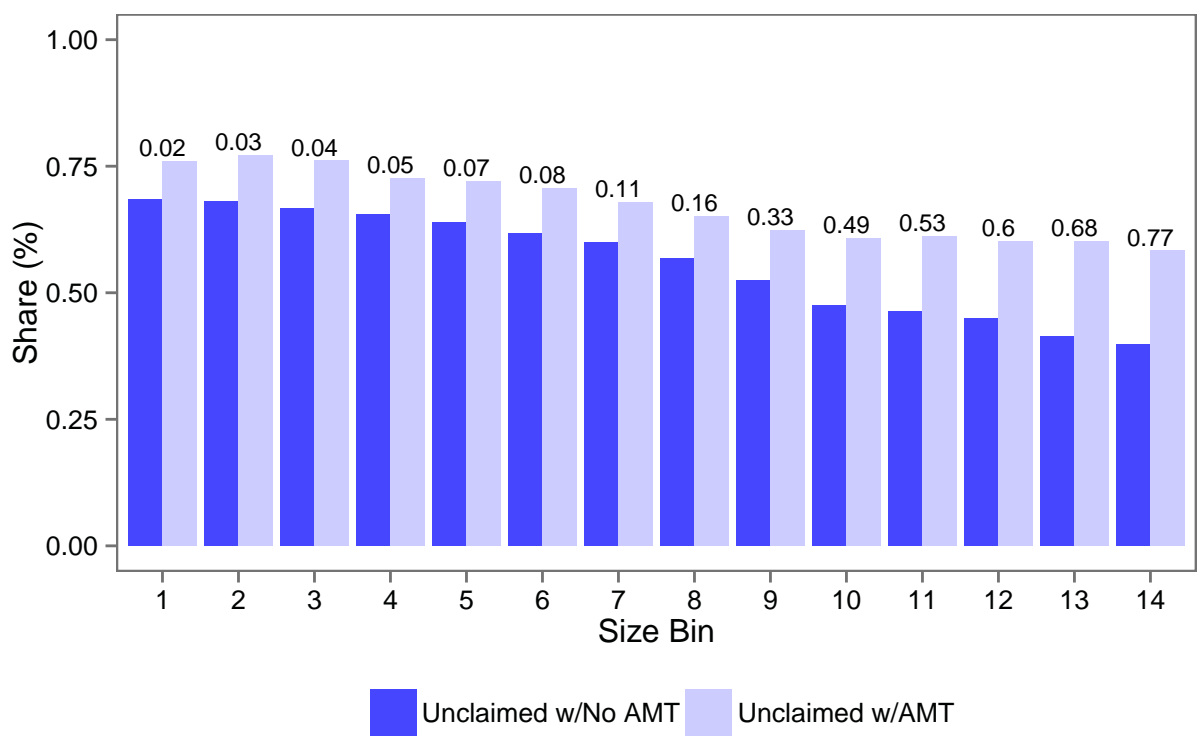

(b) Claim Rates for Tax Credit Claimers

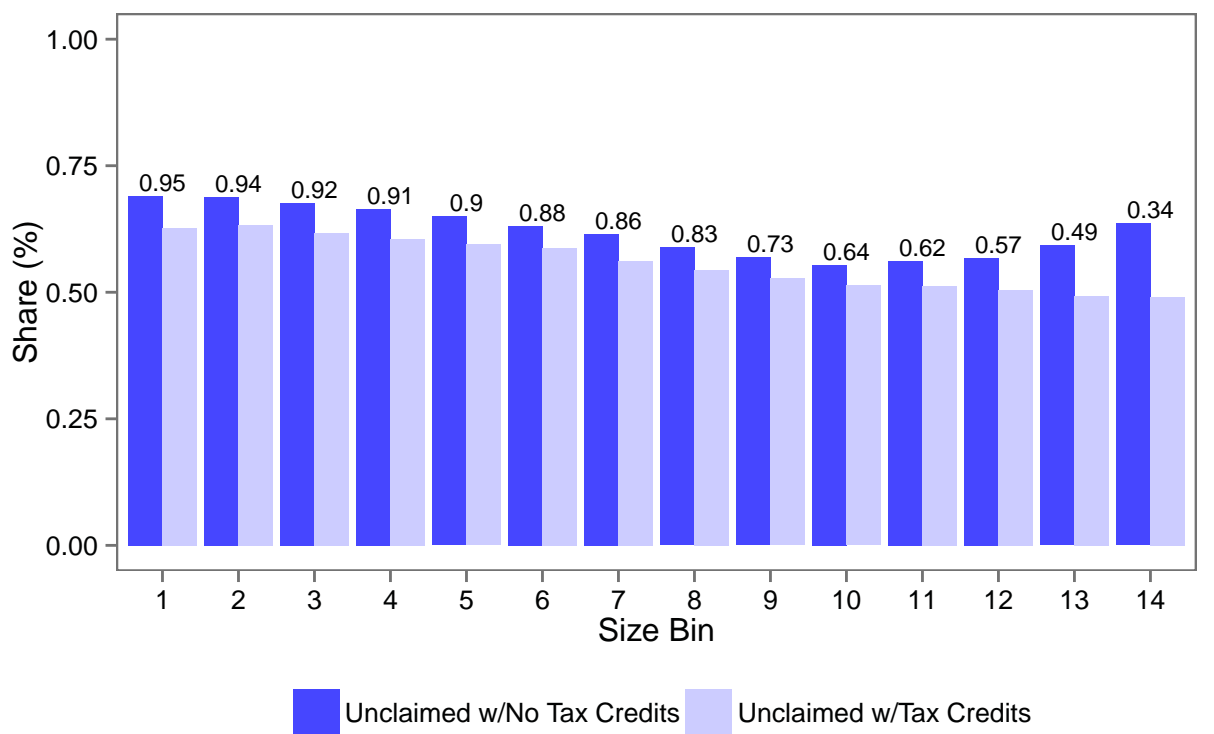

Notes: This figure documents carryback claiming behavior by firm size and alternative measures of tax return complexity. Panel (a) plots the share of refunds unclaimed for firms that have never paid the alternative minimum tax (AMT) and for firms that have paid the AMT at some time. The statistic above the bars reports the share of observations in that size bin that have paid the AMT at some time. Panel (b) plots the share of refunds unclaimed for firms that have never claimed other tax credits and for firms that have claimed other tax credits at some time. The statistic above the bars reports the share of observations in that size bin that have never claimed other tax credits. The sample includes firms that have the option to claim a carryback refund between 1998 and 2011. We exclude firms with mean revenue and mean payroll less than $\$ 100,000$. Size bins 1 through 9 demarcate the first nine deciles of the main analysis sample firm size distribution in mean sales. Size bins 10 through 14 divide the tenth decile into 2-percent bins. 
Table 1: Legislative Background on Tax Loss Carrybacks and Carryforwards, 1998-2011

\begin{tabular}{llll}
\hline Ending fiscal period $^{\mathrm{a}}$ & Carryback & Carryforward & Enacting legislation \\
\hline 1998-12 to 2000-12 & 2 years & 20 years & TRA 1997 (permanent) \\
2001-01 to 2002-12 & 5 years & 20 years & JCWAA 2002 (temporary) \\
2003-01 to 2007-12 & 2 years & 20 years & TRA 1997 (permanent) \\
$2008-01$ to 2010-11 & 5 years & 20 years & ARRA 2009 (temporary) \\
& & & WHBAA 2009 (temporary) \\
& & 20 years & TRA 1997 (permanent) \\
\hline
\end{tabular}

Notes: This table summarizes the statutory window for eligible carrybacks and carryforwards between 1998 and 2011. The policy rules apply to corporate tax returns with ending fiscal periods that fall within the range detailed in the first column of the table. The last column lists the legislation that enacted the policy changes. In this period, the carryback window was twice expanded temporarily as part of fiscal stimulus legislation. The information for this table was pulled from bulletins and revenue procedures released by the Internal Revenue Service.

a. Corporations file income taxes for the fiscal year instead of the calendar year

b. ARRA 2009 and WHBAA 2009 limited deductions against the fifth fiscal year preceding a firm's current tax loss to 50 percent of taxable income

c. TRA: Taxpayer Relief Act of 1997

d. JCWAA: Job Creation and Worker Assistance Act of 2002

e. ARRA: American Recovery and Reinvestment Act of 2009

f. WHBAA: Worker, Homeowner, and Business Assistance Act of 2009 
Table 2: Illustrative Comparison of Carryback and Carryforward Decisions

\begin{tabular}{lcccccc}
\hline & \multicolumn{7}{c}{ Event time relative to loss year } \\
\cline { 2 - 7 } & -2 & -1 & 0 & 1 & 2 & 3 \\
\hline Taxable income before loss deduction & 50 & 100 & -100 & 0 & 100 & 100 \\
\hline Panel A: Carryback Election & & & & & & \\
\hline Loss deduction & -50 & -50 & +100 & 0 & 0 & 0 \\
Taxable income after loss deduction & 0 & 50 & 0 & 0 & 100 & 100 \\
NPV of carryback election & & & $\mathbf{3 5}$ & & & \\
\hline Panel B: Carryforward Election & \multicolumn{7}{c}{} & & & \\
\hline Loss deduction & 0 & 0 & +100 & 0 & -100 & 0 \\
Taxable income after loss deduction & 50 & 100 & 0 & 0 & 0 & 100 \\
NPV of carryforward election & & & & 30.6 & \\
\hline
\end{tabular}

Notes: This table illustrates the application of carryback and carryforward deductions for a firm that reports a tax loss of $\$ 100$ at time $t=0$. Panel A assumes that the firm makes the carryback election and Panel B assumes that the firm makes the carryforward election. The illustration also assumes that the firm pays a tax rate of $\tau=0.35$ and has a discount rate of $r=0.07$. Under the carryback election in Panel A, the hypothetical firm applies its loss deduction against its past taxable income. It starts with the earliest eligible tax year $(t=-2)$ and then proceeds to the next tax year $(t=-1)$. Under the carryforward election in Panel $\mathrm{B}$, the hypothetical firm applies its loss deduction against its future taxable income. In this example, we assume that the firm claims the loss deduction as early as possible $(t=2)$. Even though this hypothetical firm always pays the same tax rate, the net present value of these two elections differ because they realize the tax benefits at different times. The carryback election realizes the tax benefits immediately at time $t=0$ as a tax refund. In contrast, the carryforward election defers the tax benefits until time $t=2$ when it claims its loss deduction. In this example, the carryback election has a higher net present value than the carryforward election because it realizes its tax benefit earlier. 
Table 3: Summary Statistics: Population and Switcher Sample, 1998-2011

(a) Carryback Eligible Corporations

\begin{tabular}{lcccc}
\hline & Mean & P10 & P50 & P90 \\
\cline { 2 - 5 } & & & & \\
Firm Variables & & & & \\
Revenue $(\$ 1 \mathrm{M})$ & 42.189 & 0.307 & 1.485 & 12.442 \\
Assets $(\$ 1 \mathrm{M})$ & 91.631 & 0.048 & 0.489 & 6.394 \\
Payroll $(\$ 1 \mathrm{M})$ & 5.336 & 0.103 & 0.469 & 3.356 \\
EBITDA (\$1M) & 2.020 & -0.118 & 0.079 & 0.603 \\
EBITDA / Revenue & -0.101 & -0.092 & 0.046 & 0.296 \\
Refund Variables & & & & \\
Take-up of Carryback Refund & 0.3742 & & & \\
Eligible Refund (\$1K) & 286.490 & 1.463 & 5.696 & 70.670 \\
Eligible Refund / Revenue & 0.0415 & 0.0008 & 0.0042 & 0.0281 \\
Preparer Variables & & & & \\
Has Matching Tax Return & 0.7107 & & & \\
Labor Income (\$1K) & 127.824 & 5.080 & 99.450 & 269.583 \\
Mean Client Revenue (\$1M) & 9.676 & 0.463 & 1.339 & 7.323 \\
Number of Corporate Clients & 51.55 & 8.00 & 37.99 & 103.26 \\
Tax Firm Variables & & & & \\
Has Matching Tax Return & 0.7673 & & & \\
Revenue (\$1M) & 132.119 & 0.136 & 0.785 & 10.741 \\
Firm is Sole Proprietorship & 0.1637 & & & \\
Mean Client Revenue (\$1M) & 7.738 & 0.538 & 1.577 & 7.031 \\
Number of Corporate Clients & 498.35 & 21.51 & 98.49 & 539.88 \\
\hline
\end{tabular}

(b) Sample with Preparer Switches

\begin{tabular}{lcccc}
\hline & Mean & P10 & P50 & P90 \\
\cline { 2 - 5 } Firm Variables & & & & \\
$\quad$ Revenue (\$1M) & 24.877 & 0.338 & 1.873 & 23.370 \\
Assets (\$1M) & 38.817 & 0.063 & 0.650 & 15.285 \\
Payroll (\$1M) & 5.027 & 0.103 & 0.572 & 5.801 \\
EBITDA (\$1M) & 0.525 & -0.228 & 0.075 & 0.796 \\
EBITDA / Revenue & -0.149 & -0.109 & 0.037 & 0.264 \\
Refund Variables & & & & \\
Take-up of Carryback Refund & 0.3572 & & & \\
Eligible Refund (\$1K) & 233.866 & 1.566 & 7.045 & 125.411 \\
Eligible Refund / Revenue & 0.0506 & 0.0007 & 0.0042 & 0.0298 \\
Preparer Variables & & & & \\
I(Certified Public Accountant) & 0.8314 & & & \\
I(Attorney) & 0.0214 & & & \\
I(Other Professional License) & 0.0556 & & & \\
log(Labor Income) & 11.36 & 9.98 & 11.57 & 12.51 \\
I(Self-Employment) & 0.1794 & & & \\
Age & 49.89 & 35.52 & 50.00 & 63.48 \\
log(Mean Client Revenue) & 14.59 & 13.06 & 14.27 & 16.62 \\
\hline
\end{tabular}

Notes: Number of observations: 1,244,729 in Panel (a) and 124,862 in Panel (b). Number of firms: 612,070 in Panel (a) and 62,431 in Panel (b). Panel (a) reports summary statistics for all C corporations with tax losses between 1998-2011 that were eligible for a carryback refund of at least $\$ 1,000$. The sample is derived from the U.S. population of corporate tax returns. All dollar values are normalized to 2013 price levels. The firm variables are based on the corporate tax return. EBITDA refers to earnings before interest, taxes, depreciation, and amortization. See Appendix A for details about how we construct these measures from the individual line items on the corporate income tax return. We directly observe take-up of the carryback refund, but we impute the eligible refund based on the policy rules and each firm's historical tax liability. The preparer and tax firm variables are based on their matching tax returns. Their statistics exclude observations that do not have a matching tax return. Labor income equals the sum of W- 2 wages and self-employment income. Mean client revenue refers to the corporate clients of each preparer and each tax firm. Percentiles are computed as percentile means. 
Table 4: Tabulation of Firm Characteristics by Size Group (Population, 1998-2011)

\begin{tabular}{|c|c|c|c|c|c|c|c|c|c|c|c|c|}
\hline \multirow[b]{2}{*}{ Bin } & \multicolumn{5}{|c|}{ Firm Characteristics } & \multicolumn{5}{|c|}{ Refund Facts } & \multicolumn{2}{|c|}{ Aggregates } \\
\hline & $\overline{\text { Sales }}$ & Unique $N$ & $\overline{\text { Payroll }}$ & EBITDA & External? & Refund & Claim? & Eligible $N$ & Always? & Never? & Eligible \$ & Claim \$ \\
\hline 1 & $340 \mathrm{~K}$ & 72934 & $220 \mathrm{~K}$ & $46 \mathrm{~K}$ & 0.928 & $4.9 \mathrm{~K}$ & 0.313 & 1.7 & 0.148 & 0.525 & $610 \mathrm{M}$ & $270 \mathrm{M}$ \\
\hline 2 & $580 \mathrm{~K}$ & 67547 & $240 \mathrm{~K}$ & $66 \mathrm{~K}$ & 0.945 & $5.8 \mathrm{~K}$ & 0.316 & 1.8 & 0.146 & 0.510 & $720 \mathrm{M}$ & $320 \mathrm{M}$ \\
\hline 3 & $800 \mathrm{~K}$ & 64874 & $320 \mathrm{~K}$ & $83 \mathrm{~K}$ & 0.950 & $7.2 \mathrm{~K}$ & 0.329 & 1.9 & 0.150 & 0.489 & $890 \mathrm{M}$ & $420 \mathrm{M}$ \\
\hline 4 & $1.1 \mathrm{M}$ & 62756 & $400 \mathrm{~K}$ & $94 \mathrm{~K}$ & 0.952 & $8.8 \mathrm{~K}$ & 0.341 & 2.0 & 0.154 & 0.467 & $1.1 \mathrm{~B}$ & $530 \mathrm{M}$ \\
\hline 5 & $1.5 \mathrm{M}$ & 60875 & $510 \mathrm{~K}$ & $110 \mathrm{~K}$ & 0.956 & $11 \mathrm{~K}$ & 0.356 & 2.0 & 0.159 & 0.441 & $1.4 \mathrm{~B}$ & $700 \mathrm{M}$ \\
\hline 6 & $2.0 \mathrm{M}$ & 59641 & $670 \mathrm{~K}$ & $130 \mathrm{~K}$ & 0.958 & $14 \mathrm{~K}$ & 0.375 & 2.1 & 0.169 & 0.416 & $1.8 \mathrm{~B}$ & $950 \mathrm{M}$ \\
\hline 7 & $2.9 \mathrm{M}$ & 58205 & $930 \mathrm{~K}$ & $170 \mathrm{~K}$ & 0.959 & $20 \mathrm{~K}$ & 0.392 & 2.1 & 0.177 & 0.388 & $2.5 \mathrm{~B}$ & $1.4 \mathrm{~B}$ \\
\hline 8 & $4.5 \mathrm{M}$ & 57724 & $1.4 \mathrm{M}$ & $200 \mathrm{~K}$ & 0.960 & $32 \mathrm{~K}$ & 0.419 & 2.2 & 0.189 & 0.353 & $3.9 B$ & $2.3 \mathrm{~B}$ \\
\hline 9 & $8.7 \mathrm{M}$ & 55837 & $2.4 \mathrm{M}$ & $280 \mathrm{~K}$ & 0.960 & $65 \mathrm{~K}$ & 0.442 & 2.2 & 0.200 & 0.320 & $8.1 \mathrm{~B}$ & $5.1 \mathrm{~B}$ \\
\hline 10 & $15.3 \mathrm{M}$ & 10819 & $3.9 \mathrm{M}$ & $300 \mathrm{~K}$ & 0.962 & $130 \mathrm{~K}$ & 0.460 & 2.3 & 0.207 & 0.289 & $3.1 \mathrm{~B}$ & $1.9 \mathrm{~B}$ \\
\hline 11 & $20.8 \mathrm{M}$ & 10692 & $5.4 \mathrm{M}$ & $300 \mathrm{~K}$ & 0.960 & $180 \mathrm{~K}$ & 0.458 & 2.3 & 0.199 & 0.287 & $4.4 \mathrm{~B}$ & $2.7 \mathrm{~B}$ \\
\hline 12 & $31.7 \mathrm{M}$ & 10457 & $10.2 \mathrm{M}$ & $370 \mathrm{~K}$ & 0.955 & $260 \mathrm{~K}$ & 0.460 & 2.4 & 0.193 & 0.282 & $6.4 \mathrm{~B}$ & $4.0 \mathrm{~B}$ \\
\hline 13 & $62.8 \mathrm{M}$ & 10078 & $13.9 \mathrm{M}$ & $200 \mathrm{~K}$ & 0.946 & $580 \mathrm{~K}$ & 0.459 & 2.5 & 0.182 & 0.261 & $14.5 B$ & $8.8 \mathrm{~B}$ \\
\hline 14 & $1.96 \mathrm{~B}$ & 9629 & $197 \mathrm{M}$ & $97 \mathrm{M}$ & 0.786 & $12.1 \mathrm{M}$ & 0.460 & 2.6 & 0.164 & 0.220 & $300 \mathrm{~B}$ & $155 B$ \\
\hline
\end{tabular}

Notes: This table presents statistics for firm and refund characteristics with firms grouped and ordered by size bin based on mean firm-level sales over all years between 1996 and 2011 for which a firm files a tax return. The underlying data are all carryback eligible firm-year observations in the main analysis sample. Except where otherwise noted, the reported statistics are means. Sales and $\overline{\text { Payroll }}$ are firm-level means of sales and total W-2 plus 1099-MISC labor payments over all years between 1996 and 2011 for which a firm files a tax return. Unique $N$ is the count of distinct firms (EINs). EBITDA is EBITDA as defined in Appendix A in the year of the loss event. External? is an indicator for whether the tax return indicates presence of an external tax preparer. Refund is the simulated eligible refund. Claim? is an indicator for whether the refund was claimed. Eligible $N$ is the number of potential refunds for a firm between 1998 and 2011. Always? is an indicator for whether a firm always claims a refund when eligible, defined only for firms where Eligible $N$ exceeds 1. Never? is an indicator for whether a firm never claims a refund when eligible, defined only for firms where Eligible $N$ exceeds 1 . Eligible $\$$ are total eligible refunds across firm-year observations. Claim $\$$ are total claimed refunds across firm-year observations. All dollar values are normalized to 2013 price levels. 
Table 5: Refund Claims and Preparer Characteristics

(a) Switcher Sample, 1998-2011

\begin{tabular}{|c|c|c|c|c|c|c|}
\hline & \multicolumn{6}{|c|}{ LHS Variable is I(Claimed Refund) } \\
\hline & (1) & (2) & (3) & (4) & (5) & (6) \\
\hline $\mathrm{I}(\mathrm{CPA})$ & $\begin{array}{c}0.0681^{* * *} \\
(0.0055)\end{array}$ & & & & & $\begin{array}{c}0.0590 * * * * \\
(0.0062)\end{array}$ \\
\hline I(Attorney) & $\begin{array}{c}0.0474 \ldots * 4 \\
(0.0124)\end{array}$ & & & & & $\begin{array}{c}0.0387^{*} \\
(0.0130)\end{array}$ \\
\hline I(Other License) & $\begin{array}{c}0.0099 \\
(0.0080)\end{array}$ & & & & & $\begin{array}{c}0.0092 \\
(0.0087)\end{array}$ \\
\hline $\log$ (Labor Income) & & $\begin{array}{c}0.0074 * * * \\
(0.0014)\end{array}$ & & & & $\begin{array}{c}0.0042 * * * * \\
(0.0015)\end{array}$ \\
\hline I(Self-Employment) & & & $\begin{array}{c}-0.0205^{* * *} \\
(0.0045)\end{array}$ & & & $\begin{array}{c}-0.0158 * * * * \\
(0.0046)\end{array}$ \\
\hline Age & & & & $\begin{array}{c}0.0003 \\
(0.0002)\end{array}$ & & $\begin{array}{c}0.0006^{* * * *} \\
(0.0001)\end{array}$ \\
\hline $\log ($ Mean Client Revenue) & & & & & $\begin{array}{c}0.0179 * * * * \\
(0.0017)\end{array}$ & $\begin{array}{c}0.0091 * * * \\
(0.0024)\end{array}$ \\
\hline Firm FE, Year FE, Controls & Yes & Yes & Yes & Yes & Yes & Yes \\
\hline Number of observations & 124,862 & 124,862 & 124,862 & 124,862 & 124,862 & 124,862 \\
\hline
\end{tabular}

(b) Deaths/Movers Sample, 1998-2011

\begin{tabular}{|c|c|c|c|c|c|c|}
\hline & \multicolumn{6}{|c|}{ LHS Variable is I(Claimed Refund) } \\
\hline & (1) & (2) & (3) & (4) & (5) & (6) \\
\hline $\mathrm{I}(\mathrm{CPA})$ & $\begin{array}{c}0.0857 * * * \\
(0.0219)\end{array}$ & & & & & \\
\hline I(Attorney) & $\begin{array}{c}0.0728 \\
(0.0526)\end{array}$ & & & & & \\
\hline I(Other License) & $\begin{array}{l}0.0551 * \\
(0.0319)\end{array}$ & & & & & \\
\hline $\log$ (Labor Income) & & $\begin{array}{c}0.0073 \\
(0.0050)\end{array}$ & & & & \\
\hline I(Self-Employment) & & & $\begin{array}{c}0.0095 \\
(0.0151)\end{array}$ & & & \\
\hline Age & & & & $\begin{array}{c}0.0007 \\
(0.0005)\end{array}$ & & \\
\hline log(Mean Client Revenue) & & & & & $\begin{array}{l}0.0162 \% * \\
(0.0068)\end{array}$ & \\
\hline Predicted Preparer Effect & & & & & & $\begin{array}{c}0.9372 * * * \\
(0.1880)\end{array}$ \\
\hline Firm FE, Year FE, Controls & Yes & Yes & Yes & Yes & Yes & Yes \\
\hline Number of observations & 9,824 & 9,824 & 9,824 & 9,824 & 9,824 & 9,824 \\
\hline
\end{tabular}

Notes: This table reports coefficients from regressions of carryback take-up on preparer characteristics. All regressions include a firm fixed effect, a tax year fixed effect, and firm controls. Firm controls include log(eligible refund), $\log$ (revenue), $\log$ (assets), and $\log$ (EBITDA), and an indicator for negative EBITDA. Panel (a) includes all switching events, and Panel (b) is limited to switching events contemporaneous with either the death or relocation of the prior preparer. The sample only includes the last observation before a client changes its preparer and the first observation after a client changes its preparer. In columns (1) and (6), preparers that do not have a professional license are the omitted certification category. The predicted preparer effect in Panel (b), column (6) is constructed using the estimated coefficients from Panel (a), column (6). Standard errors are clustered at the firm level. 
Table 6: Refund Claims and IV Predicted Preparer Effects (Deaths/Movers Sample, 1998-2011)

\begin{tabular}{|c|c|c|c|}
\hline & (1) & (2) & (3) \\
\hline Predicted Preparer Effect & $\begin{array}{c}1.1780 * * * * \\
(0.3839)\end{array}$ & $\begin{array}{c}0.9950 * * * \\
(0.3774)\end{array}$ & $\begin{array}{l}0.7532^{* * *} \\
(0.3728)\end{array}$ \\
\hline Firm FE & Yes & Yes & Yes \\
\hline Year FE & No & Yes & Yes \\
\hline Firm controls & No & No & Yes \\
\hline Number of observations & 9,824 & 9,824 & 9,824 \\
\hline
\end{tabular}

Notes: This table reports coefficients from a two-stage least squares regression of carryback take-up on preparer characteristics. The predicted preparer effect is constructed using the estimated coefficients from Panel (a), column (6) of Table 5. The instrument equals the preparer covariate in the pre-event period and the sample mean for the preparer covariate in the post-event period. All regressions include a firm fixed effect. Column (2) adds a tax year fixed effect. Column (3) adds firm controls, which include log(eligible refund), $\log$ (revenue), $\log ($ assets), $\log ($ EBITDA), and an indicator for negative EBITDA. The sample is limited to switching events contemporaneous with either the death or relocation of the prior preparer. It only includes the last observation before a client changes its preparer and the first observation after a client changes its preparer. Relocations are defined based on moving personal residences to a new zip code at least 75 miles away. Standard errors are clustered at the firm level. 


\section{A Variable Definitions from the Business Tax Data}

We pull line items from the income tax return, Form 1120, to describe characteristics of the tax loss firms in our sample. Here, we explain how we construct the variables reported in Table 3. All dollar amounts are normalized to 2013 price levels. Revenue equals total income (line 11) plus cost of goods sold (line 2). Assets is reported in box D on the front page of Form 1120. Payroll is the sum of W-2 and 1099-MISC wage statements. Firms issue these statements to employees and contractors respectively. EBITDA is defined as total income (line 11) minus total deductions (line 27) plus compensation of officers (line 12) plus interest (line 19) plus charitable contributions (line 19) plus depreciation (line 20) plus depletion (line 21) plus the domestic production activities deduction (line 25).

We identify the paid preparer that assisted a corporation with filing their tax return from Form 1120. On the bottom of the front page of the tax form, preparers hired to file an income tax return must self-identify themselves and their employing firm. This field does not include internal employees that prepare their employer's income tax return.

We construct measures of preparers using the identifiers reported on Form 1120. We match these identifiers to their individual income tax returns. We obtain our age variable from a social security file that records the date of birth. We also compute average client characteristics and the number of clients from the population of $\mathrm{C}$ and $\mathrm{S}$ corporations by preparer and tax year. Similarly, we match tax firm identifiers to income tax returns for sole-proprietorships, partnerships, and corporations to construct our measures for tax firms. 


\section{B Simulation of Tax Refunds for the Carryback Election}

The IRS does not automatically compute the eligible carryback refund each time a corporation files an income tax return that reports a net operating loss. Instead, the IRS requires firms to provide documentation that details the computation of their refund when they file for it. To determine whether firms are eligible for carryback refunds, we simulate eligible refunds based on each firm's reported loss, their history of taxes paid in prior tax years, and the policy rules detailed in Table 1 . We validate the accuracy of our simulated refunds by comparing them to claimed refunds.

Specifically, we identify each corporate tax return that reports a net operating loss. For each firm, we pull their tax liability history and incorporate any post-filing adjustments to their past tax returns. We then infer each firm's past taxable income using their past tax liabilities. This assumption ignores adjustments to tax liability from Schedule J of Form 1120, such as the application of tax credits and the alternative minimum tax. We next apply the reported loss against our simulation of past taxable income according to the policy rules in Table 1 . We start by deducting the loss against the earliest eligible tax year and progress in calendar order, until we have exhausted either the loss or all eligible taxable income. We then re-compute the firm's tax liability based on their new taxable income in each past tax year. Finally, we calculate the carryback refund by taking the difference in the firm's tax liability before and after applying the carryback deduction.

We check the credibility of our simulation of eligible carryback refunds by comparing them to the observed refunds received by firms that claim the carryback. Figure A.1 plots means of $\log$ (claimed refunds) by vigintiles of $\log$ (simulated refunds). A univariate regression of $\log$ (claimed refunds) on $\log$ (simulated refunds) yields a coefficient of 0.9636 and a R-squared of 0.9336. These results imply that we simulate the eligible carryback refunds with a high degree of accuracy.

\section{Simulation of Carryforward Deductions}

We compute the net present values of the carryback and carryforward elections by simulating future carryforward deductions. For each firm, we use the observed taxable income in future tax periods. We first compute the amount of tax loss available for carryforward deductions. For firms that elect the carryback, this amount equals the remaining amount of deductions that could not be applied to past taxable income. For firms that elect the carryforward, this amount equals the full loss reported at time $t=0$. 
We then simulate the claiming of the carryforward deduction against future taxable income. We assume that firms deduct the carryforwards as soon as possible. Our simulation can also account for firms that have an existing stock of carryforwards prior to time $t=0$. In these cases, we first deduct from the stock of pre-existing carryforwards before we deduct the carryforwards generated by the tax loss at time $t=0$. This treatment increases the delayed realization of the tax benefits from the carryforwards.

Figure A.1: Claimed carryback refunds vs. simulated carryback refunds

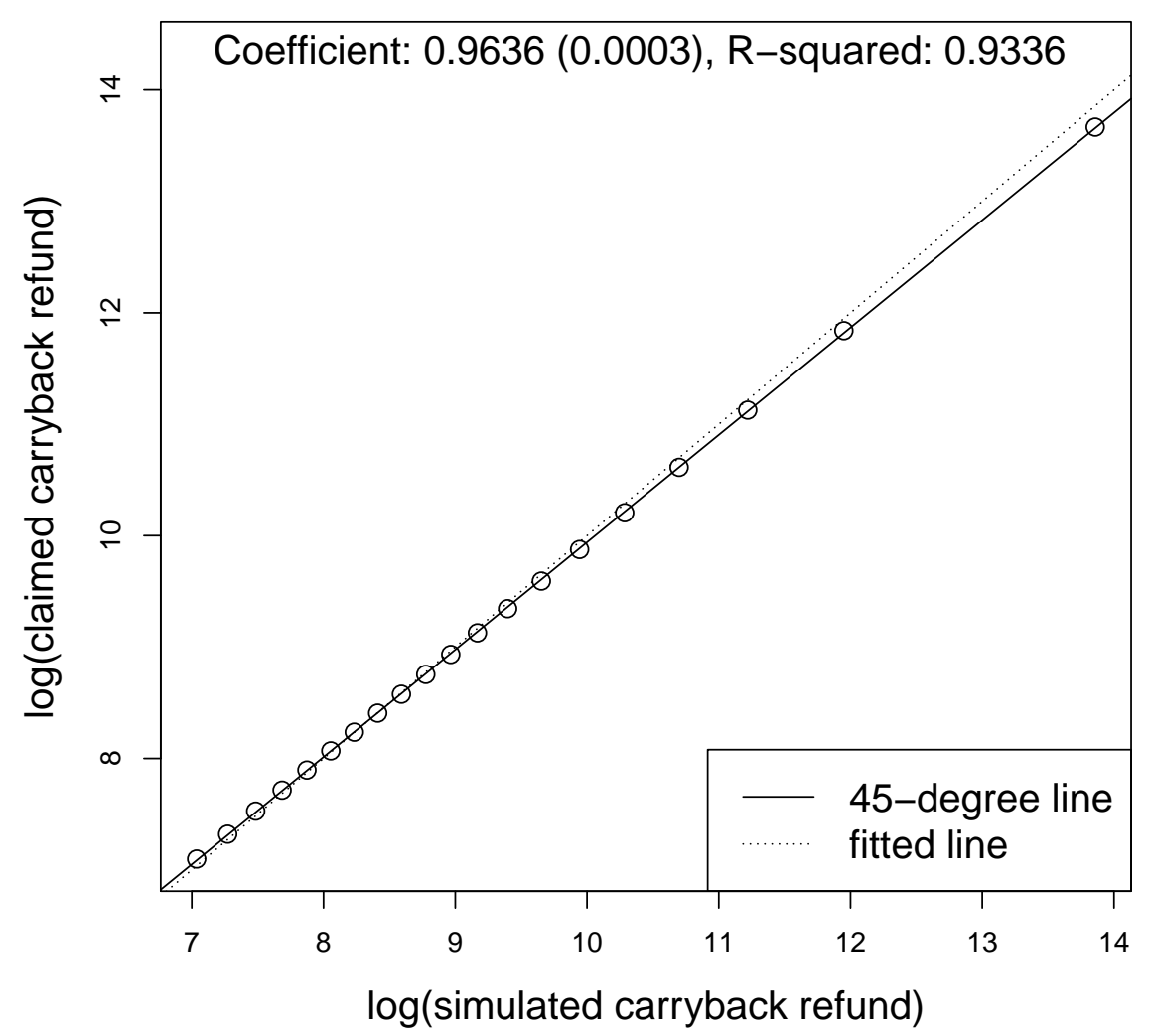

Notes: This figure compares claimed carryback refunds to simulated carryback refunds. The sample includes all firms that (i) report a net operating loss, (ii) have simulated eligible refunds of at least $\$ 1,000$, and (iii) claim (and receive) a carryback refund. The figure plots mean $\log$ (claimed carryback refund) by vigintiles in $\log$ (simulated carryback refund). It also reports the slope coefficient and the R-squared from a regression of $\log$ (claimed carryback refund) on $\log$ (simulated carryback refund). The simulation of eligible carryback refunds are based on each firm's tax loss, historical tax liability, and the policy rules for carryback refunds. 


\section{Background on Corporate Tax Credits (Tax Year 2016)}

1. Foreign Tax Credit: An FTC is given to U.S. corporations that pay income, war profits, or excess profits taxes to foreign countries or U.S. possessions. Excess foreign tax credits can either be carried back 1 year or carried forward 10 years to offset taxes in the same category (Form 1118, Line 5a).

2. Qualified Electric Vehicle Credit: This tax credit can be used to reduce taxable income for vehicles that are "propelled to a significant extent by an electric motor that draws electricity from a battery that can be recharged from an external source of electricity." There was a maximum of $\$ 2,500$ in recent years per vehicle, and the credit could be used for vehicles used for both business and personal use (Form 8834, Line 5b).

3. American Samoa Economic Development Credit: The American Samoa credit can be used to reduce taxable income for qualified production that takes place in American Samoa (Form 5735, Line 5b).

4. Investment Tax Credit: The Investment Tax Credit is a credit that can be used for qualifying advanced coal projects, qualifying gasification projects, qualifying advanced energy projects (solar, wind, geothermal), rehabilitating older buildings, or the use of qualifying "energy property" such as fuel cells or wind turbines (Form 3468, line 5c).

5. Credit for Increasing Research Activities: The research credit is for research that is undertaken for discovering information that is "technological in nature, and its application must be intended for use in developing a new or improved business component of the taxpayer." The research must relate to a new or improved function, performance, reliability, or quality (Form 6765, line 5c).

6. Low-Income Housing Credit: The LIHC is a tax credit for new or rehabilitated affordable, residential rental buildings. A certain percentage of the units in each building are "reserved" for renters with incomes below a certain threshold with the rent capped for those units (Form 8586, line 5c).

7. Disabled Access Credit: Taken by certain small businesses for reasonable expenses that they incur for the purpose of providing access to persons with disabilities. These expenses include removing barriers that a prevent a business from being accessible to persons with disabilities, providing interpreters and readers, or purchasing or modifying equipment (Form 8826, line 5c).

8. Renewable Electricity, Refined Coal, and Indian Coal Production Credit: This tax credit is for renewable energy products including wind facilities, biomass facilities, geothermal energy facilities, solar energy facilities, landfill gas or trash facilities, and small irrigation power facilities. The credit can also be used for refined coal production or coal produced from coal reserves owned by an Indian tribe or held in trust by the U.S. for the benefit of an Indian tribe (Form 8835, line 5c).

9. Indian Employment Credit: This credit is meant to give businesses an incentive to hire individuals who live on or near Indian reservations. The tax credit is for employees who 
are enrolled members of an Indian tribe or the spouse of an enrolled member, who make less the $\$ 45,000$, who perform most of their services within an Indian reservation and have their home near or on that reservation (Form 8845, line 5c).

10. Orphan Drug Credit: This credit is for $50 \%$ of qualified clinical testing expenses paid or incurred during the tax year for rare diseases or conditions (those that affect less than 200,000 people in the U.S.) or for diseases or conditions "for which there is no reasonable expectation of recovering the cost of developing and making available a drug in the United States for the disease from sales of the drug in the United States" (Form 8820, line 5c).

11. New Markets Tax Credit: The NMTC allows corporations to receive a credit (39\% over 7 years) against income taxes for making equity investments in community development entities (CDEs) that are expected to result in the creation of jobs and material improvement in the lives of residents of low-income communities where at least $20 \%$ of individuals live below the poverty line or the median family income does not exceed $80 \%$ of the median family income (Form 8874, line 5c).

12. Small Employer Pension Plan Startup Costs Credit: For small employers (those with fewer than 100 employees), this credit is for 50\% of qualified startup costs (up to $\$ 500$ ) incurred in establishing and administering an eligible employer pension plan (Form 8881, line 5c).

13. Credit for Employer-Provided Child Care Facilities and Services: This credit is for $25 \%$ of qualified childcare facility expenditures plus $10 \%$ of qualified resource and referral expenditures up to $\$ 150,000$. These expenditures include acquiring, constructing, rehabilitating, or expanding property that will be used as part of a childcare facility, operating a childcare facility, or expenses as part of a contract with a facility to provide childcare services to employees of the taxpayer (Form 8882, line 5c).

14. Biodiesel and Renewable Diesel Fuels Credit: The biodiesel credit is $\$ 1.00$ for each gallon of biodiesel or renewable diesel that is either used by the taxpayer in the production of a biodiesel mixture, used as fuel, or sold by the taxpayer and placed in a fuel tank. A credit of 10 cents can be taken by small agri-biodesel producers for each gallon of agri-biodiesel produced (Form 8864, line 5c).

15. Low Sulfur Diesel Fuel Production Credit: The credit is generally 5 cents for every gallon of low sulfur diesel fuel produced by a small business refiner (Form 8896, line $5 c)$.

16. Distilled Spirits Credit: For wholesalers, the Distilled Spirits credit is a credit of 8 cents per case of bottled distilled spirits (Form 8906, line 5c).

17. Nonconventional Source Fuel Credit: The Nonconvetional Source Fuel Credit is a credit of $\$ 3$ per barrel-of-oil equivalent for coke or coke gas that was produced and sold. The fuel could not have been produced in a facility that produces coke or coke gas from petroleum-based products (line $5 \mathrm{c}$, currently just a carryforward). 
18. Energy Efficient Home Credit: The Energy Efficient Home Credit is for contractors who construct an energy efficient home. The credit is $\$ 2,000$ for homes that meet a $50 \%$ energy efficient standard and \$1,000 for homes that meet a 30\% energy efficient standard (Form 8908, line 5c).

19. Energy Efficient Appliance Credit: The Energy Efficient Appliance Credit is for producers of energy efficient appliances, including dishwashers, clothes washers, and refrigerators. There was a limit of $\$ 25$ million dollars or $4 \%$ of average gross receipts per taxpayer (line 5c, currently just a carryforward).

20. Alternative Motor Vehicle Credit: The Alternative Motor Vehicle Credit is a credit for four-wheeled vehicles that are powered by fuel cells (Form 8910, line 5c).

21. Alternative Fuel Vehicle Refueling Property Credit: This credit is for property that is used to store or dispense an alternative fuel into the fuel tank of a motor vehicle or recharge an electric car. The credit is for $30 \%$ of the cost up to $\$ 30,000$ per location for each business (Form 8911, line 5c).

22. Mine Rescue Team Training Credit: For businesses that employ miners in underground mines, this credit is for $20 \%$ of the cost of training program costs paid to train qualifying full-time employees (up to $\$ 50,000$ per employee) (Form 8923, line 5c).

23. Agricultural Chemicals Security Credit: This credit is for manufacturers or sellers of agricultural products for costs paid to protect specific agricultural chemicals including fertilizers and pesticides. The credit is for 30\% of the costs up to $\$ 100,000$ per facility and $\$ 2,000,000$ per taxpayer (carryforward, line $5 c$ ).

24. Credit for Employer Differential Wage Payments: This credit is for differential wage payments (all or a portion of the wages the employee would have received from the employer if the employee were working for the employer) made by employers to employees who are performing active duty service in the U.S. armed forces. Before 2015, this credit only applied to qualified small businesses. The credit is for $20 \%$ of up to $\$ 20,000$ of payments paid to each employee (Form 8932, line 5c).

25. Carbon Dioxide Sequestration Credit: This credit is for carbon dioxide that is captured and either disposed of or used in an enhanced oil or natural gas recovery project (Form 8933, line 5c).

26. Qualified Plug-In Electric Drive Motor Vehicle Credit: For new four-wheeled vehicles that are propelled to a significant extent by an electric motor that draws electricity from a battery, or two-wheeled vehicles that go at least 45 miles per hour and are propelled to a significant extent by an electric motor (Form 8936, line 5c).

27. Qualified Plug-In Electric Vehicle Credit: For any electric vehicle passive activity credit from prior years (Line 5c, currently just a carryforward).

28. New Hire Retention Credit: The New Hire Retention Credit was for businesses that hired an employee between February 2010 and January 2011 if the employee worked for at 
least 52 weeks and did not have their wages decrease significantly during the second 26 weeks. The credit was for $6.2 \%$ of the employees' wages, but could not be larger than $\$ 1,000$ (Line 5 c, currently just a carryforward).

29. General Credits from an Electing Large Partnership: This is a partner's share of General Credits from a large partnership, excluding the Low-Income Housing Credit, the Rehabilitation Credit from Rental Real Estate, and the Foreign Tax Credit (Schedule K-1 (Form 1065-B), line 5c).

30. Credit to Holders of Tax Credit Bonds: This is a tax credit that holders of certain bonds receive in addition to or instead of receiving regular interest payments. These bonds include clean renewable energy bonds, energy conservation bonds, zone academy bonds, school construction bonds, and Build America bonds. Holders have to hold the bond on particular allowance dates in order to claim the credit (Form 8912, line 5e).

31. Enhanced Oil Recovery Credit: This credit is for $15 \%$ of the costs of any project that is expected to result in more than an insignificant increase in the amount of oil that will be recovered, or any amount paid to construct an Alaska natural gas plant (Form 8830, line 5c). Carryforwards from credits related to the Trans-Alaska pipeline liability fund; employers affected by Hurricane Katrina, Rita, or Wilma; the Hurricane Katrina housing credit; affected Midwestern disaster area employers; the employer tax credit; contributions to selected community development corporations; welfare-to-work; and the New York Liberty Zone; as well as for some credits paid in the mid-2000s are included on the same line.

32. Work Opportunity Credit: The Work Opportunity Credit is a credit for the wages paid to targeted group employees, including long-term family assistance recipients, TANF recipients, veterans, ex-felons, SNAP recipients, SSI recipients, long-term unemployment recipients, summer youth employees, designated community residents, and vocational rehabilitation referrals. The maximum amount the credit can cover per employee is based on the type of targeted group employee and the number of hours worked (Form 5884, line 5c).

33. Biofuel Producer Credit: This is a tax credit for is sold by the second generation biofuel (a liquid fuel that is derived from feedstocks) that is sold by the producer for use in the buyer's trade or business or to a buyer who sells the biofuel at retail. The credit is for $\$ 1.01$ per gallon sold (Form 6478, line 5c).

34. Credit for Employer Social Security and Medicare Taxes Paid on Certain Employee Tips: This credit is for food and beverage establishments that pay social security and medicare taxes on employee tips. The credit only includes taxes paid on tips above the federal minimum wage of $\$ 5.15$ per hour that was in effect at the beginning of 2007 (Form 8846, line 5c).

35. Qualified Railroad Track Maintenance Credit: The RTMC can be claimed by select taxpayers for expenditures for maintaining, repairing, and improving a railroad structure (Form 8900, line 5c). 
36. Small Employer Health Insurance Premiums Credit: This credit is for eligible small employers for premiums paid for certain health insurance coverage provided to employees enrolled in a health plan offered through the Small Business Health Options Program. In recent years, the credit in only available for a period of 2 consecutive tax years (Form 8941, line 5c).

37. Credit for Prior Year Minimum Tax-Corporations: This is a credit for minimum tax paid in the year prior, or minimum tax carryforwards from previous years. This can be used to offset current-year income above the minimum tax (Form 8827, line 5d).

38. Credit for Federal Tax Paid on Fuels: This is a refundable tax credit for certain uses of fuels, including farm use, export, off-highway business use, use in a commercial fishing boat, use in local buses, use by nonprofit education organizations, use by states or local governments, and for use by military aircraft (Form 4136, line 19b). 